ANL-6189

Reactors - Power

(TID-4500, 15th Ed.)

AEC Research and

Development Report

ARGONNE NATIONAL LABORATORY

9700 South Cass Avenue

Argonne, Illinois

\title{
OPERATIONAL TESTS OF \\ EBWR VAPOR RECOVERY SYSTEM
}

by

R. J. Gariboldi and D. R. Jacobson

Reactor Engineering Division

August 1960

Operated by The University of Chicago under

Contract W-3l-109-eng-38 


\section{DISCLAIMER}

This report was prepared as an account of work sponsored by an agency of the United States Government. Neither the United States Government nor any agency Thereof, nor any of their employees, makes any warranty, express or implied, or assumes any legal liability or responsibility for the accuracy, completeness, or usefulness of any information, apparatus, product, or process disclosed, or represents that its use would not infringe privately owned rights. Reference herein to any specific commercial product, process, or service by trade name, trademark, manufacturer, or otherwise does not necessarily constitute or imply its endorsement, recommendation, or favoring by the United States Government or any agency thereof. The views and opinions of authors expressed herein do not necessarily state or reflect those of the United States Government or any agency thereof. 


\section{DISCLAIMER}

Portions of this document may be illegible in electronic image products. Images are produced from the best available original document. 
TABLE OF CONTENTS

$\underline{\text { Page }}$

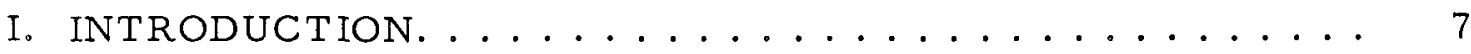

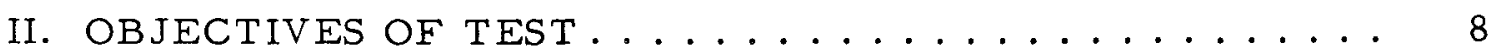

III. DESCRIPTION OF VAPOR RECOVERY SYSTEM . . . . . . . 9

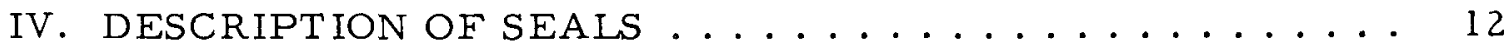

A. Turbine Seal, High-pressure End............. 12

B. Turbine Seal, Low-pressure End ............ 12

C. Turbine Horizontal Flange Joint Seal .......... 12

D. Throttle Valve Seal .................... 14

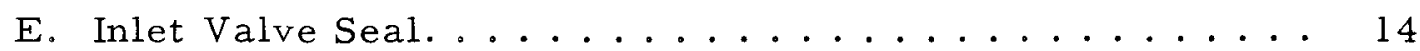

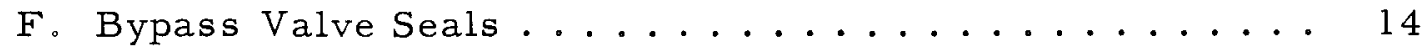

G. Feed Pump Seals....................... 14

V. DESCRIPTION OF TEST APPARATUS............ 18

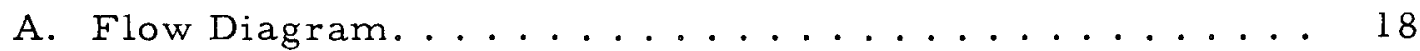

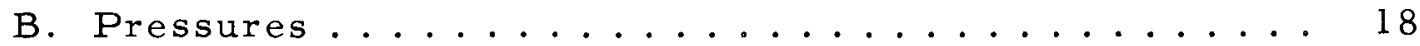

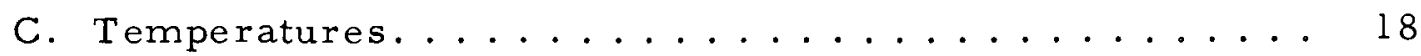

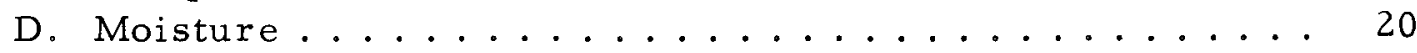

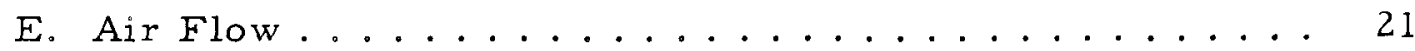

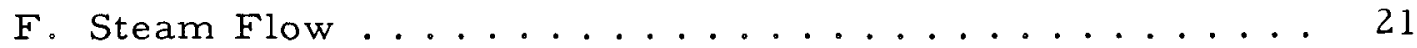

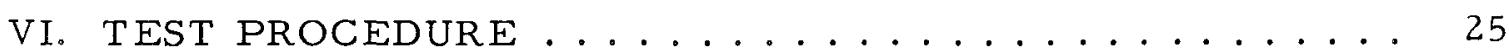

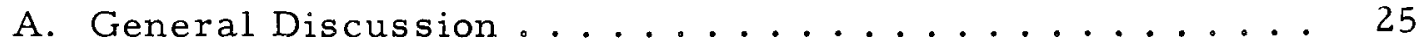

B. Steam Plant Conditions during tests ........... 25

C. Specific Procedure for First-phase Tests ......... 25

D. Specific Procedure for Second-phase Tests ........ 26

VII. TEST RESULTS AND OBSERVATIONS . . . . . . . . . . 29

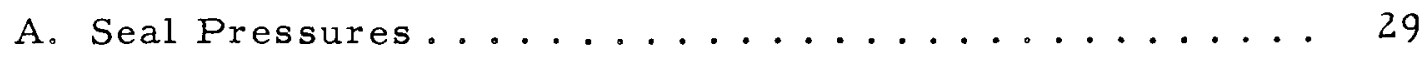

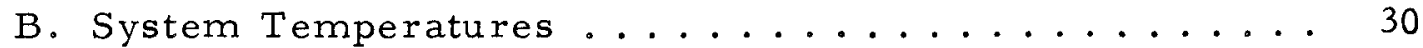

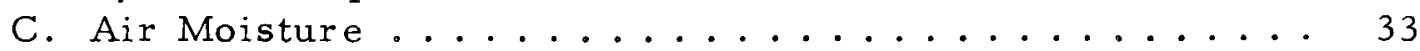

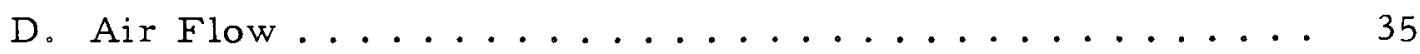

1. Flow Rates with "Design" Seal Pressures....... 39

2. Flow Rates with "Operating Average" Seal Pressures. 39

3. Seal Characteristics ..................... 39

4. Labyrinth Seal, Flow Model, and Derivation of

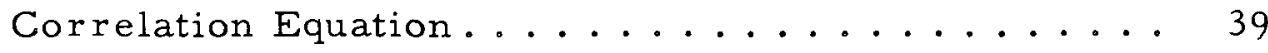


TABLE OF CONTENTS

$\underline{\text { Page }}$

E. Seal Steam and Seal Water Flows . . . . . . . . . . . . 42

F. Leakage and Contamination............... 43

G. Observed Abnormalities .................. 44

1. Failure of Recovered Air Reactivation Loop Blower . . 44

2. Valve and Pump Seals ................. 44

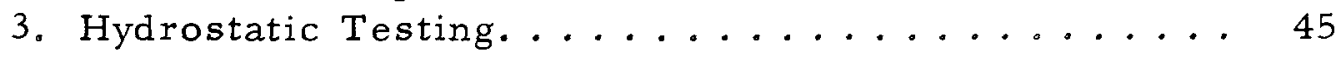

4. Makeup Air Desiccator Cooling........... 45

5. Seal Air Pressure Controller ............ 45

VIII. CONCLUSIONS. ...................... 46

IX. RECOMMENDATIONS ..................... 47

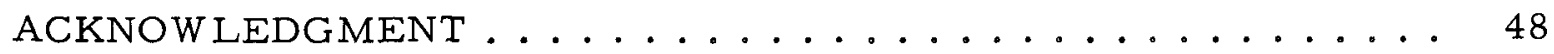

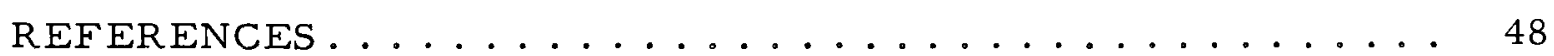




\section{LIST OF FIGURES}

No

Title

Page

1 Fluid Concentration and Seal Air Drying Equipment ...... 10

2 EBWR Turbine Shaft Seal (H.P. End) ............. 13

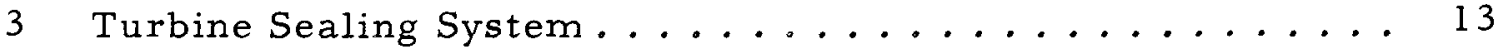

4 Turbine Seals - Original Shop Gland Clearances ........ 14

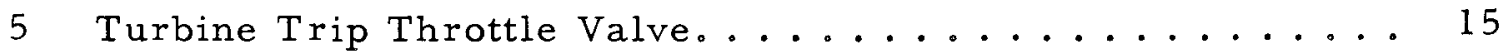

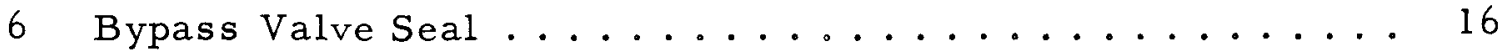

7 Cross-Sectional View of EBWR Feedwater Pump Seal. . . . . 16

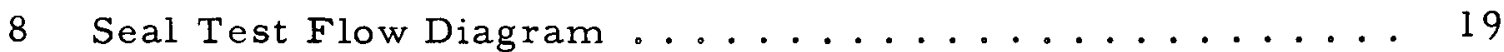

9 Turbine Seal Dry Air Supply Rotometers ........... 22

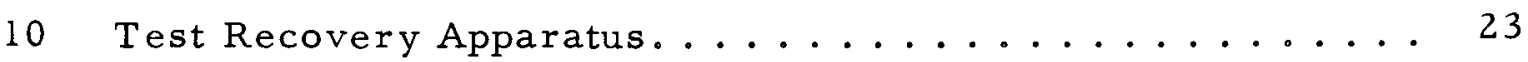

11 Turbine Air/Steam Lines from Seals ............. 24

12 Seal Chamber Pressures .................. 31

13 Typical Plot of Air Temperature After Makeup Air

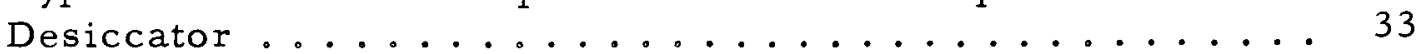

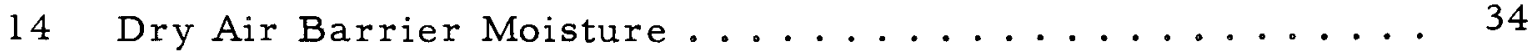

15 Seal Test on High-pressure End of EBWR Turbine...... 37

16 Seal Test on Low-pressure End of EBWR Turbine ...... 38

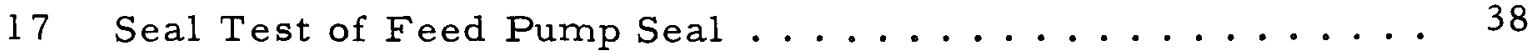

18 Ideal Flow Through 6-stage and 12 -stage Labyrinth Air Seals with $0.008-i n$. Annular Orifices............ 40

19 Labyrinth Seal, Flow Model .................. 40

20 Correlation for Turbine Rotating Labyrinth Seals, TwoComponent Flow Model .................. 42

21 Vapor Recovery with Pressurized Desiccators . . . . . . . 47 


\section{LIST OF TABLES}

No.

Title

Page

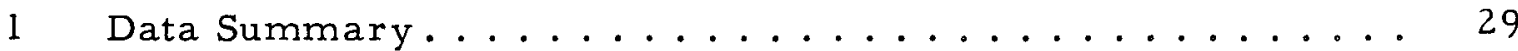

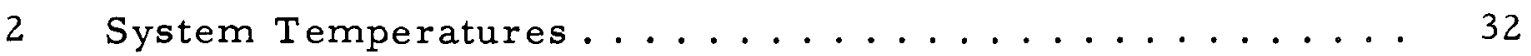

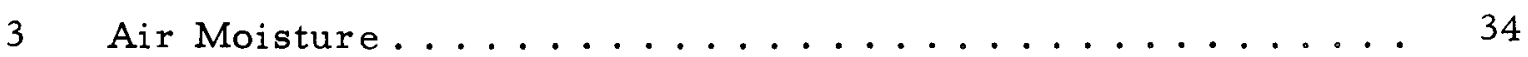

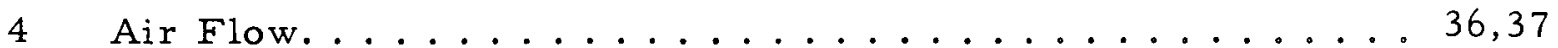

5 Seal Steam and Seal Water Flows .............. 43 
-

- 
OPERATIONAL TESTS OF EBWR VAPOR RECOVERY SYSTEM

by

R. J. Gariboldi and D. R. Jacobson

\section{INTRODUCTION}

Sargent and Lundy Engineers have recently conducted a detailed analysis of a direct-cycle boiling $\mathrm{D}_{2} \mathrm{O}$ reactor power plant for the Atomic Energy Commission. The control of $\mathrm{D}_{2} \mathrm{O}$ los is a major factor in the economic analysis of such a plant. (1) The validity of the analysis of $\mathrm{D}_{2} \mathrm{O}$ loss is strongly dependent upon the degree to which one can rely upon the capability and effectiveness of the vapor recovery system. Since the Experimental Boiling Water Reactor (EBWR) is uniquely equipped with a vapor recovery system, ANL was requested to conduct an operating test to contribute further data for $\mathrm{D}_{2} \mathrm{O}$ plant evaluations. This report describes tests conducted on EBWR to evaluate the vapor recovery system.

The EBWR is a direct-cycle boiling water reactor. The steam that is formed in the reactor core is directlyused to drive the power plant turbogenerator. The reactor is designed for operation with light water as the working fluid. However, since it is an experimental facility, the plant is designed to permit other operating modes, including operation with $\mathrm{D}_{2} \mathrm{O}$. (2)

In anticipation of the use of $\mathrm{D}_{2} \mathrm{O}$ the original plant was equipped with a vapor recovery system. Upon introduction of $\mathrm{D}_{2} \mathrm{O}$, all primary plant seals would be vented or drained to the vapor recovery system. For operation with light water as the working fluid, only the major component seals which require a dry air barrier for their operation are included in the recovery system. These components are:

1. the turbine rotor shaft seal at the high-pressure end of the turbine;

2. the turbine rotor shaft seal at the low-pressure end of the turbine;

3. the seal groove in the turbine casing joint flange;

4. the seals on the turbine inlet valve lift rods;

5. the seals of the throttle valve stem and flange; and

6. the main feed pump drive shaft and flange seals. 


\section{OBJECTIVES OF TEST}

System analysis groups have noted that a reliable prediction of $\mathrm{D}_{2} \mathrm{O}$ losses is difficult because test reports present only examples conducted under ideal conditions, and thus provide no indication of losses resulting from abnormalities. (1) Partial objectives of the tests discussed here have been to make note of abnormalities and to determine the losses possible from equipment failure or operating errors. Gross losses resulting from such conditions cannot be accurately predicted since the time period of the abnormality cannot be known in advance. The sources and relative importance of malfunctions have been studied.

Additional objectives of this test were to:

1. study the operation and design of the vapor recovery system;

2. measure the seal air operating pressures, temperatures, and moisture content;

3. measure air flow through the seals, assess seal wear, and compare the measured flow through turbine labyrinths to theoretical flow;

4. evaluate the operation of the desiccator by measuring desiccator air flow, temperature, and moisture;

5. evaluate the design of the vapor recovery system with regard to its effectiveness and its equipment ratings;

6. assume direct-cycle $\mathrm{D}_{2} \mathrm{O}$ operation of the reactor and from the test data determine the $\mathrm{D}_{2} \mathrm{O}$ leakage that would be controlled by the se seals;

7. determine the amount of contamination by atmospheric $\mathrm{H}_{2} \mathrm{O}$ that would be introduced with makeup air for the seal system; and

8. recommend improvements to the installed system and for future systems. 
III. DESCRIPTION OF VAPOR RECOVERY SYSTEM

The purposes of the EBWR vapor recovery systems are:

1. to reduce loss of the primary working fluid and radioactive gases to the containment atmosphere, and

2. to reduce contamination of the primary working fluid by air and atmospheric vapor in-leakage.

There are three principal operations of the vapor recovery system:

1. the collection of the effluent from all seals to a concentration system, by maintaining a vacuum in the collection gland at the seal and a greater vacuum in the concentration system;

2. the concentration of all reactor water leakage by means of condensers and desiccators and the return of the collected liquid to the turbine condenser hotwell; and

3. the provision of a positive pressure dry air barrier at major seals where the collection gland vacuum would otherwise draw in atmospheric air and consequently atmospheric vapor.

A schematic diagram of the fluid concentration and dry seal air supply equipment for the vapor recovery system is shown in Fig. 1.

The seal leakage is collected from the turbine, pumps, and valves together with air from the dry air barriers of the seals. This recovered air/vapor mixture is drawn into the vent condenser, where most of the vapor is condensed. Water that is already in the liquid form, such as feed pump leakage, is simply drained into the vent condenser sump. From the condenser, the recovered air passes over refrigeration coils to produce further condensation. The coils must be kept above $32^{\circ} \mathrm{F}$ to prevent frost; hence in the winter when cold cooling water is available, the coils are not loaded to capacity.

To remove all but 10 to $100 \mathrm{ppm}$ of reactor water, the recovered air is passed through an activated alumina desiccator bed. To recover the reactor water collected by the alumina, two parallel-connected desiccators are used: one is reactivated while the other is on the line. The alumina is reactivated by blowing heated air through the bed, whereby the bed releases its moisture to the warm air. The moisture is condensed in a water-cooled heat exchanger and the dry air is then recycled.

The main blowers return the dry air to the dry air barrier glands of the seals. Since the dry air glands are at a positive pressure, some dry air is lost to the atmosphere. To replace this lost air, atmospheric air is drawn into the system. This makeup air is cooled and dried to reduce the introduction of atmospheric vapor. 


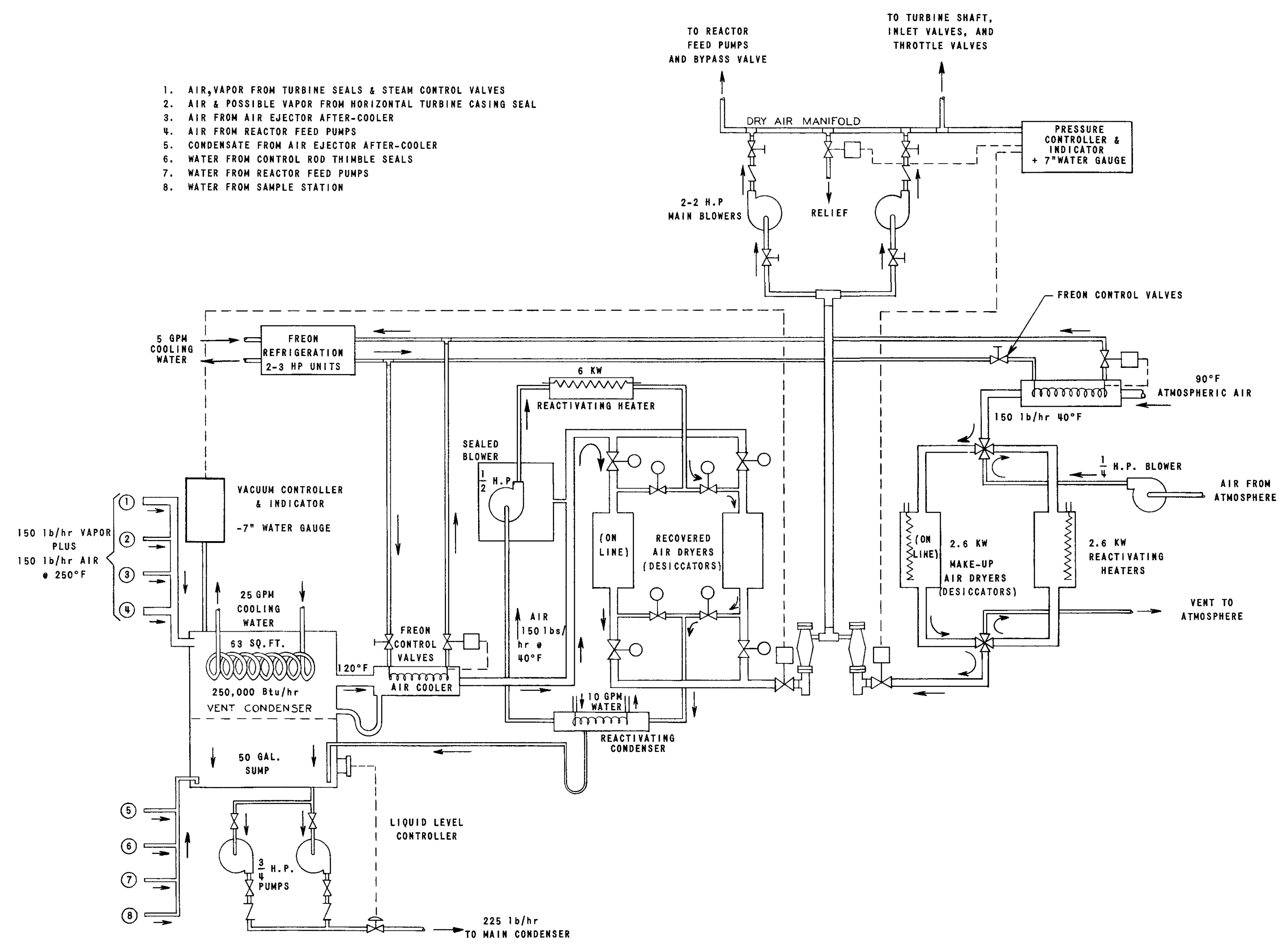


The vacuum in the vent condenser is regulated by an indicating pressure controller that operates a throttle valve at the recovered air desiccator exit. The controller has an automatic range of 0 to $10 \mathrm{in}$. water gauge vacuum, and is normally operated at $7 \mathrm{in}$. The pressure of air supplied to the seals is regulated by an indicating controller that operates a makeup air throttle valve and an overpressure relief valve. The controller automatic range is the same as above. Both controllers may be operated on "manual" to higher pressure up to the limits of the blower. The blower is capable of 30 in. of water differential head. With $150-1 \mathrm{~b} / \mathrm{hr}$ air flow, the design pressure drop through the heat exchangers and recovered air desiccators is 10 in. water gauge.

The result of proper operation of the system is that all seals have effectively zero leakage. The only primary vapor that is lost is that minute quantity entrained in the dry air lost from the dry air barrier. 
IV. DESCRIPTION OF SEALS

A. Turbine Seal, High-pressure End

The turbine shaft seal at the high-pressure end of the turbine contains four essential chambers, as depicted in Figs. 2 and 3:

1. a dry air barrier chamber containing dry air which is maintained at a pressure slightly above atmospheric (the design pressure of this chamber is +6 in. water gauge);

2. an air/steam leakage collection chamber which is maintained at a vacuum slightly below atmospheric (the design vacuum is -6 in. water gauge);

3. a seal steam chamber containing primary system steam (the steam pressure is maintained at 2 psig by venting the excess to the condenser, as indicated in Fig. 3); and

4. a steam vent chamber that is vented directly to the eighth stage of the turbine.

The steam leaking from the high-pressure end of the turbine to the vent chamber is retarded by a 24-stage labyrinth seal. A 12-point labyrinth separates each of the four chambers from one another. The dry air in the barrier chamber is retarded from leaking to the atmosphere by a 6-stage labyrinth.

Allis-Chalmers measurements of the initial shop seal clearances are presented in Fig. 4. The dimensions are representative of the annular labyrinth orifices afforded.

\section{B. Turbine Seal, Low-pressure End}

The turbine low-pressure seal, shown in Fig. 3, is a threechamber unit similar to the turbine high-pressure seal in all respects except for the omission of the 24-stage high-pressure inboard labyrinth seal section. The inward leakage of seal steam passes directly to the main condenser.

\section{Turbine Horizontal Flange Joint Seal}

At the time of the initial plant installation, a seal system composed of a vacuum leakoff channel and an external can-like air chamber was welded around the horizontal joint in the turbine casing to collect any leakage that might occur in this region. This is shown in Fig. 3. Running experience with this arrangement indicated that the leakage through the horizontal turbine joint was negligible, and in the course of servicing the 
GLAND SEAL STEAM 2 PSIg

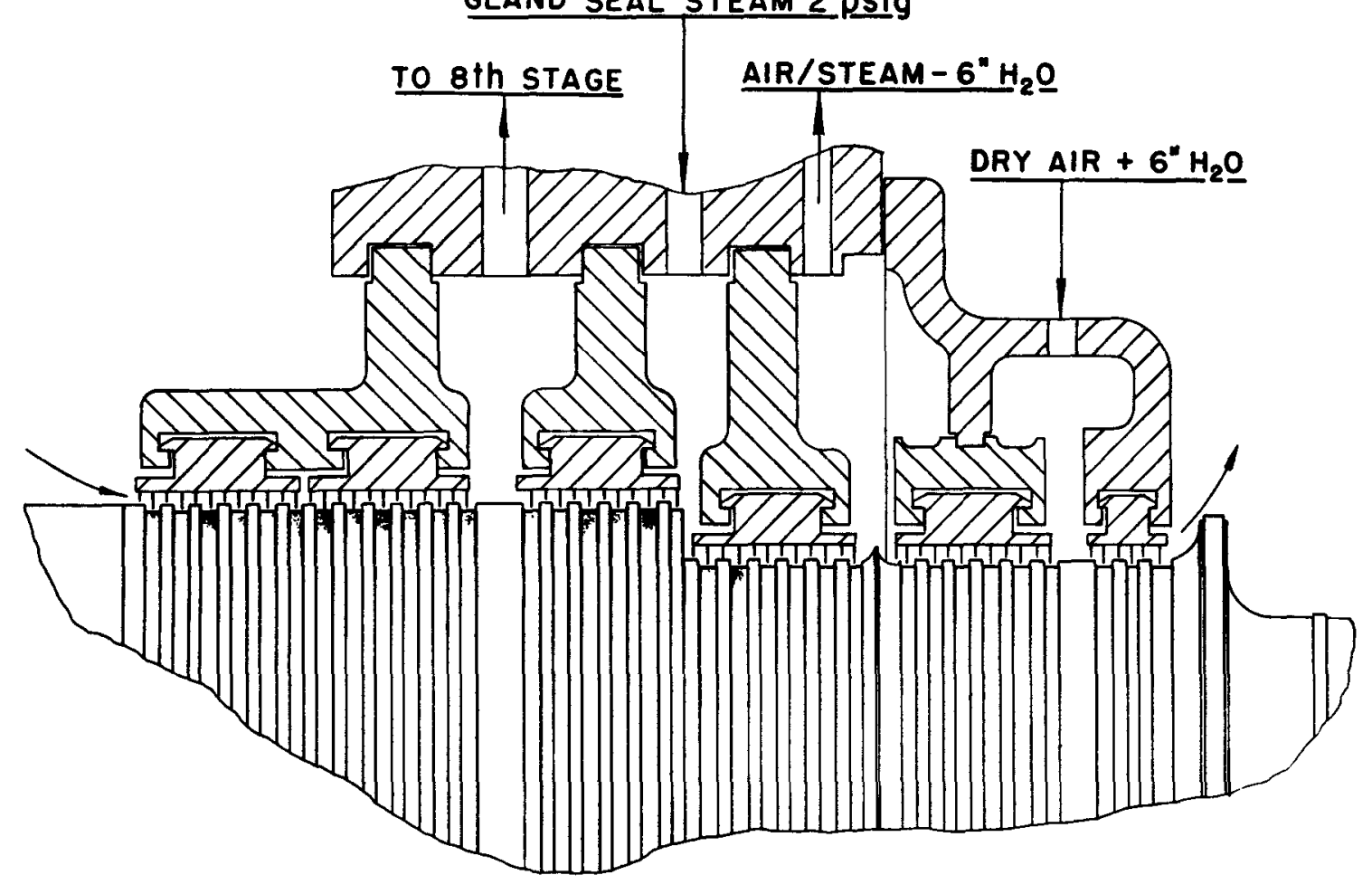

EBWR TURBINE SHAFT SEAL (H.P. END)

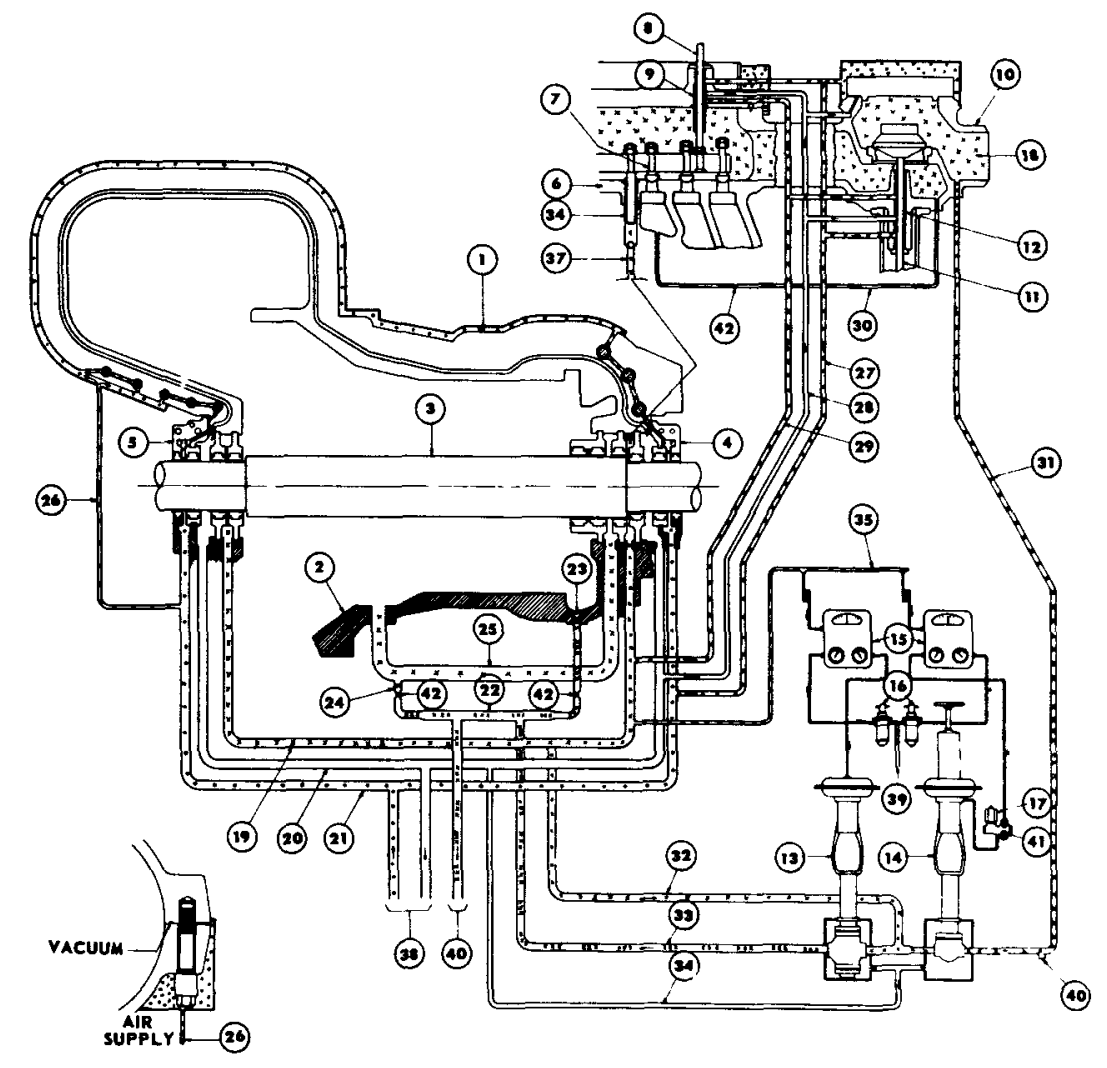

$F I G, 3$

TURBINE SEALING SYSTEM
23. STEAM ENO CASIMG DRAIN
24. LEAKOFF PIPE DRAIM

25. STEAM ENO gLand LEAKOFF and EquaL ZIIMG PIPE

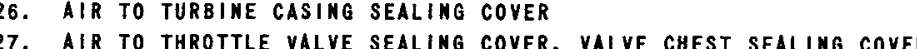

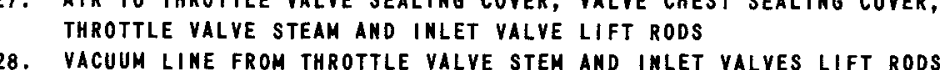

28. VACUUM LLIIE FROM THROOTLE VALLE STEH AAT IILET VALVES LIFT RODS

30. COHT INUOUS DRAIM FROM BELOW THROTTLE VALVE SEAT

32. GLAND STEAN MAKEUP OR RELLEF

34. VACUUA LIME FROM REL

. STEAM PRESSURE SEHSIMG LINE

balance rod leakoff to steam end gland

38. VAPOR RECOVERY SYSTEM
39. PLANT IR COONECTON
40. CONDENSER CONNECTION

1. CTMENASR CONNECTION
ATMOSPERIC EXHAUST

41. ATMOSPHERIC
42. ORIFICE 


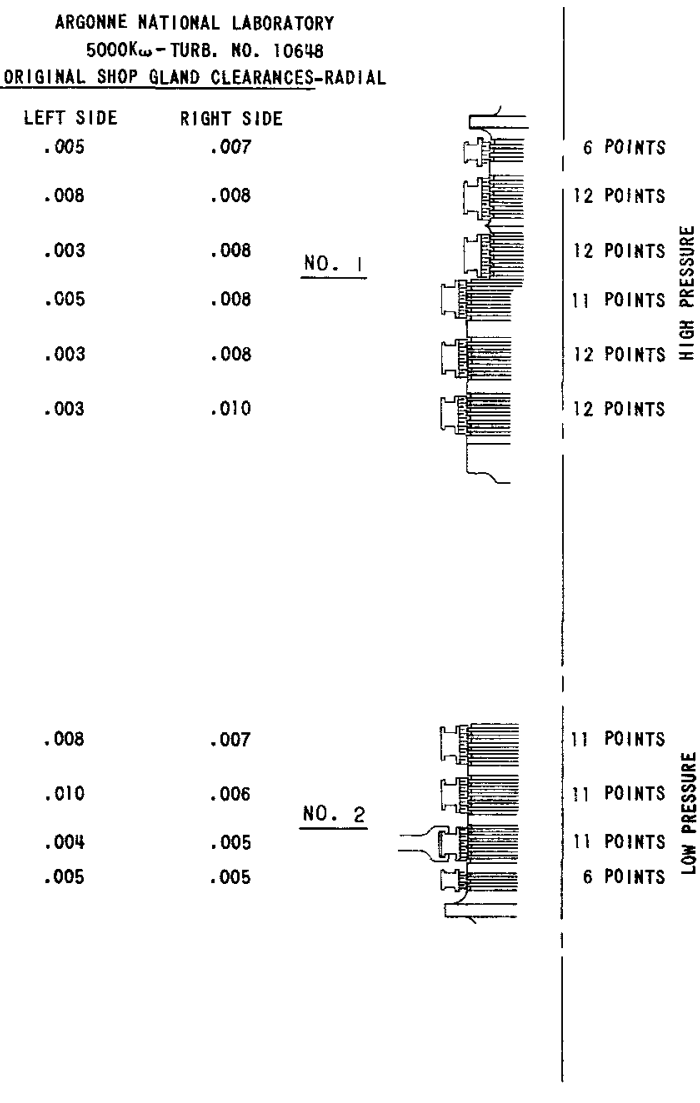

F16. 4

ORI GiNAL SHOP GLANO CLEARANCS turbine the welded can forming the dry air chamber was removed. At the present time, the air supply to the seal is closed but vacuum is still applied to the circumferential leakoff groove. The flow conditions and the possiblity of restrictions within the any in-leakage that may be collected from this from this system is being vented to the vapor recovery system via the turbine shaft collection chambers.

\section{Throttle Valve Seal}

As indicated in Fig. 5, he throttle valve seal arrangement is of a less complex design than that of the turbine seals and consists of a grooved sleeve located between the packing gland and leakoff bushing. The sleeve contains three grooves which act as dry air, vacuum, and seal steam chambers. The seal so formed operates by the same principle as the high and low-pressure

turbine seals. Interchamber flow is retarded by the close sleeve fit. Air leakage to atmosphere is virtually prevented by the valve stem packing.

\section{E. Inlet Valve Seal}

The turbine inlet valve is actuated by two lift rods. A general arrangement of the valve is shown in Fig. 3. Sealing of each lift rod is accomplished by the same method as that employed in the turbine throttle valve.

\section{F. Bypass Valve Seals} the throttle valve seal.

\section{G. Feed Pump Seals}




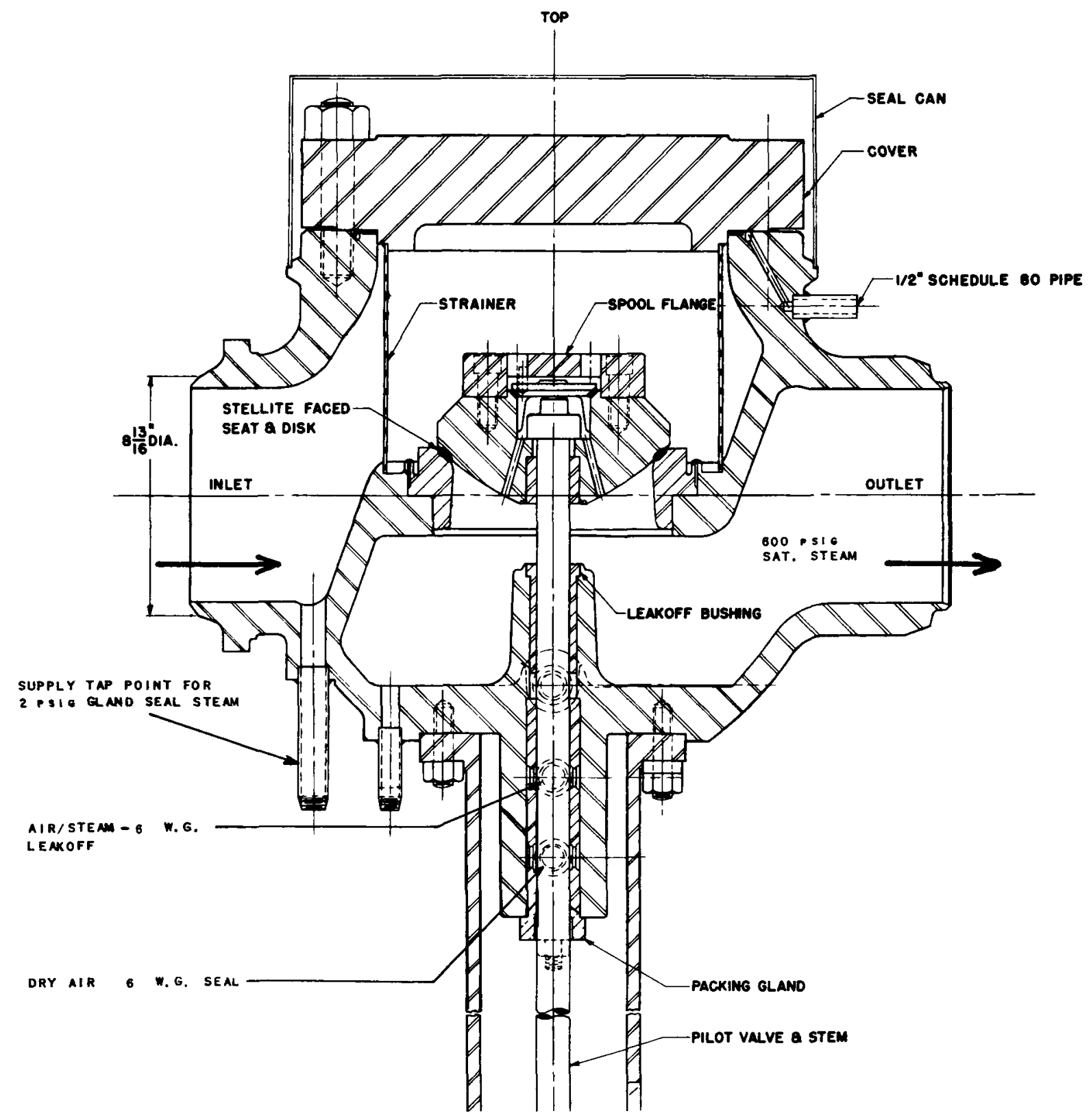

FIG. 5

TURBINE TRIP THROTTLE VALVE 


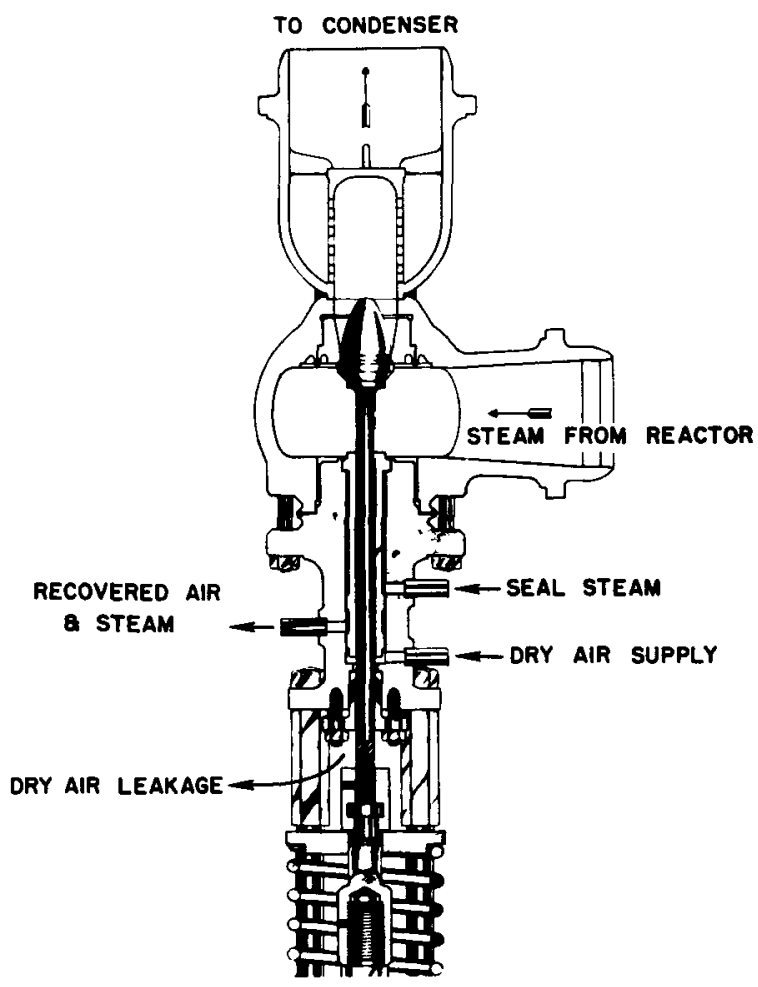

FIG. 6

BY-PASS VALVE SEAL

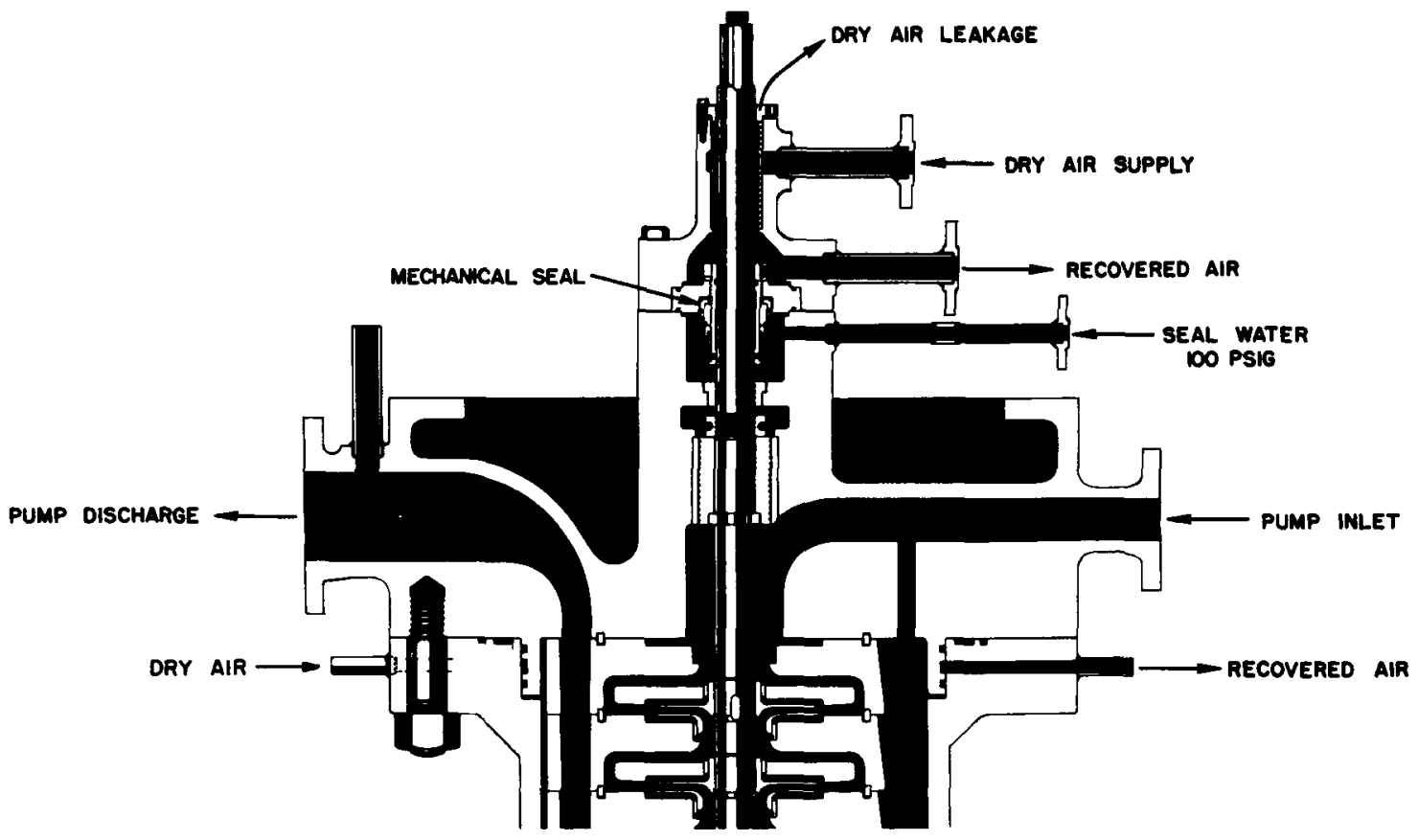

FIG. 7

CROSS-SECTIONAL VIEW OF EBWR FEEDWATER PUMP SEAL 
1. The innermost chamber is connected to the main condenser vacuum. The 900-psig water that leaks up the drive shaft is thus returned to the pump inlet.

2. The seal water chamber is connected to the 100-psig discharge of the first stage of the pump. A serrated bushing separates this chamber from the condenser vent chamber.

3. The air/water leakage collection chamber is maintained at a vacuum slightly below atmospheric by the vapor recovery system. A rotary mechanical seal, comprised of a Stellited ring operating against a graphite face, prevents the 100-psig seal water from entering this chamber.

4. The dry air barrier is similar to those of the turbine shaft and valve stems. Labyrinths are used to retard air flow to the collection chamber and to atmosphere. 
V. DESCRIPTION OF TEST APPARATUS

A. Flow Diagram

The flow diagram of Fig. 8 illustrates the location of test equipment in the vapor recovery system. The arrangement is designed to permit performance of all operational tests on any individual seal or group of seals without detrimental interference to the operation of the remaining parts of the vapor recovery system. The test system provides all the instrumentation required to accomplish the objectives listed in Section II of this report. The preliminary arrangement of apparatus was designed and the equipment sized by Sargent and Lundy Engineers. The final installed arrangement was carried out by ANL.

\section{B. Pressures}

The recovery system pressures and vacuums were all measured by standard "U"-tube manometers using fluorescein-tinted water. The seal steam pressure was measured by a bourdon tube pressure gauge. The pressure taps are indicated by the letter " $P$ " in Fig. 8.

\section{Temperatures}

During the phases of testing, temperatures were measured at the points labeled "T." The thermocouples were of No. 20 iron and constantan wire with silver-soldered junctions. Thermocouple output was recorded on two Brown multipoint recorders. All couples were calibrated with an ice bath after installation.

Thermometers were used on the: (1) dry air line manifold immediately up-stream of the turbine rotometers; (2) feed pump rotometer; (3) turbine seal return line; (4) recovered air rotometer manifold; and (5) exit line from the makeup air desiccators.

Temperature Recorders:

Brown Potentiometer

Model 157X64P16-X-41

Strip Chart, 16 point, Multipoint Recorder

Range: 0 to $100^{\circ} \mathrm{F}$ with I-C couples

Brown Potentiometer

Mode1 157X72-P8-(11)(111)16-A4A8

Strip Chart, 4 point, Multipoint Recorder

Range: 0 to $500^{\circ} \mathrm{F}$ with I-C couples 
\begin{tabular}{l} 
- LEGEND - \\
P \\
MONOMETER R RESSURE TAP \\
\hline THERMOMETER \\
M. MO ISTURE MON I TOR TAP
\end{tabular}

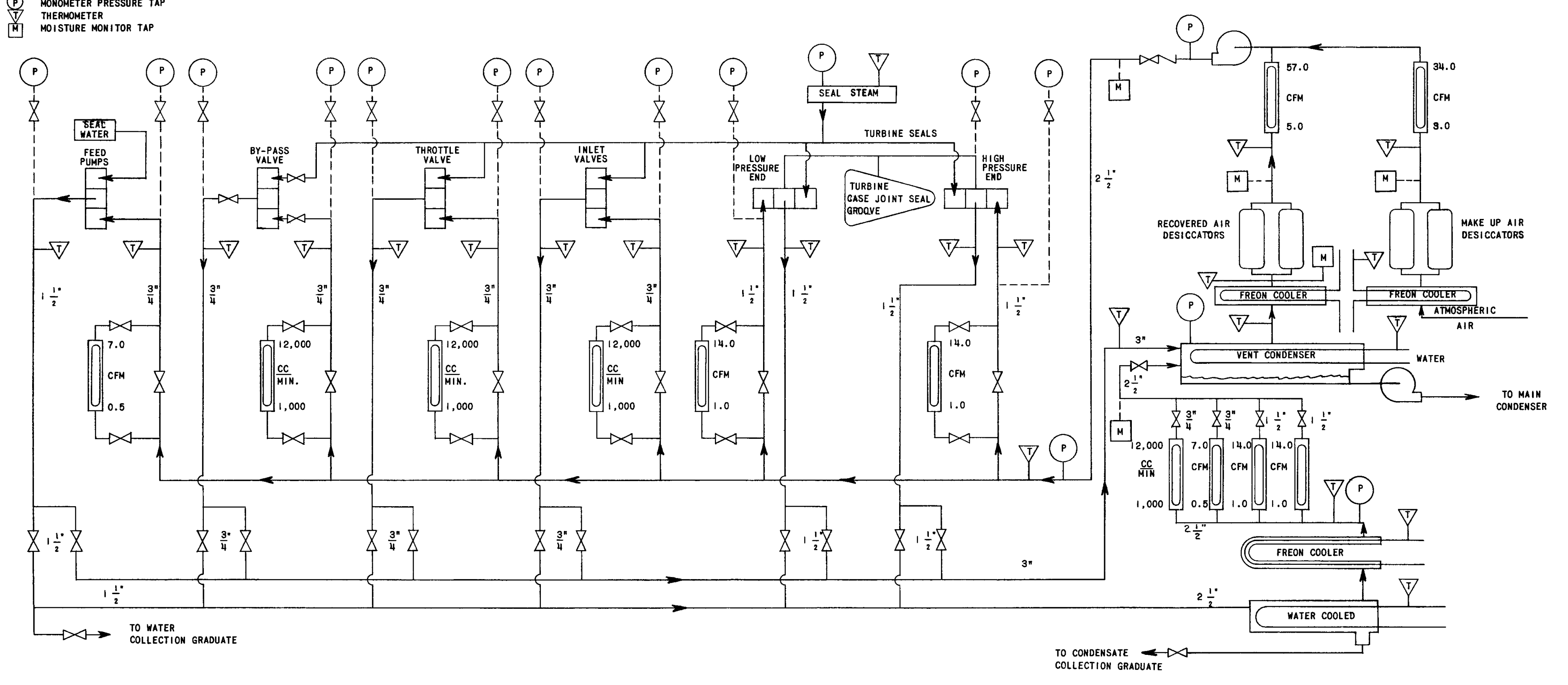


Thermometers:

American Model No. 268 with $5 \mathrm{lb}$ scale and $\frac{1}{2}$ in. NPT Class B Sockets. For the cold lines, (1)(2) and $(4), 20^{\circ} \mathrm{F}$ to $120^{\circ} \mathrm{F}$ range was used. For the hot lines, (3) and (5), $100^{\circ} \mathrm{F}$ to $400^{\circ} \mathrm{F}$ range was used.

\section{Moisture}

An extensive effort was made to obtain accurate measurements of the moisture content of the dry air supplied to the seals. Since it was known from previous tests that there was a variation in the moisture content of the air leaving the desiccators, a recording moisture monitor was used to plot the air quality at the following points:

1. dry air outlet of the recovered air desiccators;

2. dry air outlet of the makeup air desiccators; and

3. the mixture of recovered and makeup air at the outlet of the main blowers (seal air supply).

An Alnor dew point instrument was used to make an order-of magnitude spot check for the Consolidated instrument. Spot checks of air quality were also taken at the recovered air desiccator inlet and at the rotometer manifold of the test apparatus to verify air moisture saturation presumptions.

\section{Recording Hygrometer:}

Consolidated Electrodynamics

Portable Moisture Monitor, Type 26-302

Range: Highest - 1 to $20,000 \mathrm{ppm}$ by volume Lowest - 1 to $10 \mathrm{ppm}$ by volume

Sample Flow: $20 \mathrm{cc} / \mathrm{min}$

Operating Principle: Electrolysis

The instrument output signal of $0-100 \mathrm{mv}$ was recorded on a Brown, single-point, 0-100 mv, potentiometric strip chart recorder. The $100-\mathrm{mv}$ corresponded to the full scale of the monitor range in use.

Dew Point Indicator:

Illinois Testing Laboratories, Inc.

"Alnor Dew Pointer" - Type 7000 U

Dew Point Range: Room temp. to minus $80^{\circ} \mathrm{F}$

Sample: Representative

Principle: Condensation upon adiabatic expansion 


\section{E. Air Flow}

Special effort was made to assure accurate flow measurements and to introduce very little line pressure drop in so doing. Rotometers were installed in the dry air supply lines to each seal and a bank of four meters were installed after the Freon air cooler of the test apparatus to measure recovered air flow. Meter ranges and locations are indicated in Fig. 8. Figure 9 shows the installed arrangement of the rotometers under the turbine. All flow tubes were calibrated and engraved to an accuracy of $1 \%$ of full scale for $32^{\circ} \mathrm{F}, 14.696$ psia air.

Rotometers:

Fischer \& Porter Company

Flowrator Mode1 10A2735A

Flow Tubes - Borosilicate Glass

Floats: Stainless Steel (spool type in CFM meters and balls in $\mathrm{cc} /$ minute meters)

Valves:

Crane No. 430 Gate Valves

Brass body and trim

Double wedge disk

Rising stem with back seat and separate packing gland provisions for leak tightness.

\section{F. Steam Flow}

The flow rates of steam effluent from the seals was measured by condensing the vapor and timing the condensate flow to a two-liter graduate. Figure 10 shows the test vapor recovery equipment as installed in the plant. Figure $1 \mathrm{l}$ is a top view of the valves installed under the turbine to direct recovered air/steam to the test apparatus.

\section{Condenser:}

Patterson-Kelly Company

Heat exchanger Model DF6-36

Tube Bundle: 4-pass "U" tube, with $7.6 \mathrm{sq} f \mathrm{ft}$ of $\frac{3}{4}-\mathrm{in}$. OD 18 ga copper tubes

Shell-to-tube design pressure: 125 psig - water in tubes

Air Cooler:

Brown Fin Tube Company

Hairpin Shell Heat Exchanger- Model 017-000-010 counter flow Tube: "U" tube, $10 \mathrm{sq}$ ft of $1 \frac{1}{2}-$ in. steel tube

Shell-and-tube design pressure: 500 psig - Freon 12 in. tube 


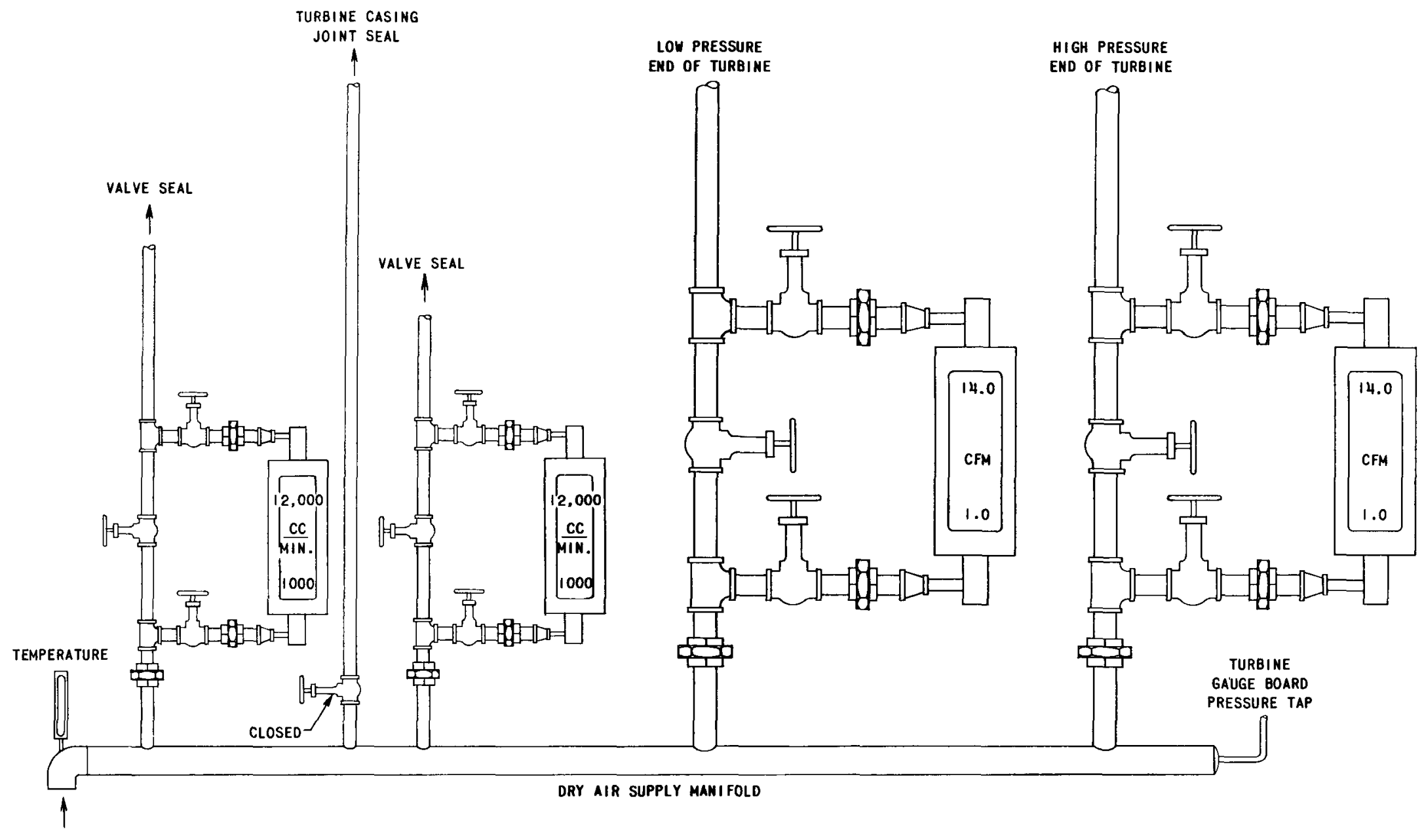

FIG. 9

TURBINE SEAL DRY AIR SUPPLY ROTOMETERS 


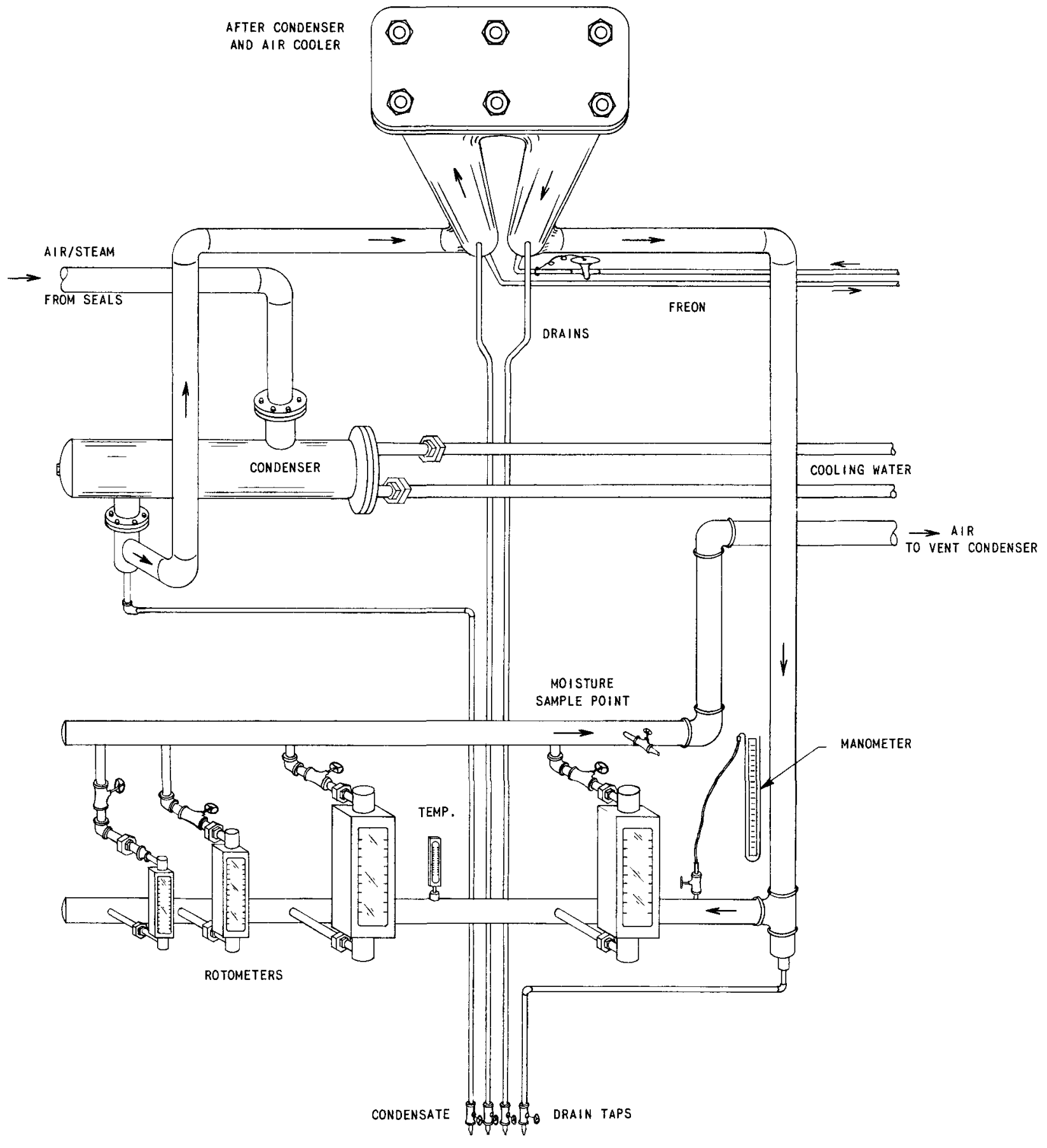

FIG. 10

TEST RECOVERY APPARATUS 


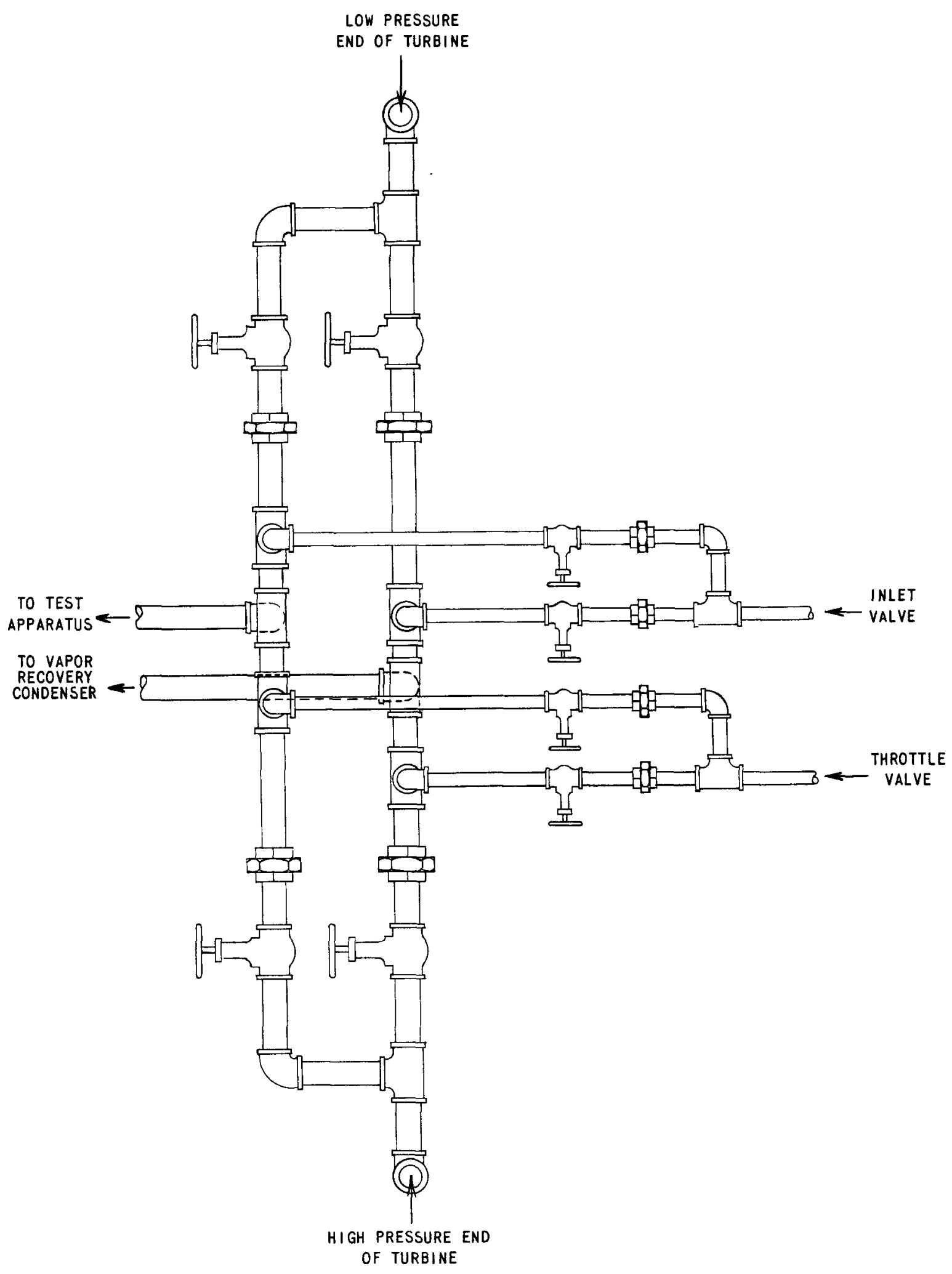

FIG.II

TURBINE AIR/STEAM LINES FROM SEALS 
VI. TEST PROCEDURE

A. General Discussion

The tests were divided into two phases. The objectives of the first-phase tests were to measure pressures, temperatures and air moisture under normal operating conditions in order to determine the

1. average operating condition,

2. normal operating fluctuations,

3. variances from design parameters, and

4. control data needed for the second-phase tests.

The objectives of the second-phase tests were to measure system air flow and water (vapor and liquid) flow with seal pressures regulated

1. to design values, i.e., to 6 in. W.G.,

2. to the average operation values determined in the first phase, and,

3. in 1 in. W. G. increments from 1 in. W.G. to 10 in. W. G., to determine seal characteristics.

B. Steam Plant Conditions during Tests

The steam plant conditions during test were those normally required to operate the turbine at $3600 \mathrm{rpm}$ with about one $\mathrm{Mw}$ of electrical load. Steam plant parameters pertinent to these tests were:

1. Turbine speed

$3600 \mathrm{rpm}$

2. Turbine power

$\sim 1000 \mathrm{kw}$

3. Reactor steam flow

$\sim 20,000 \mathrm{lb} / \mathrm{hr}$

4. Reactor pressure

600 psig

5. Main condenser vacuum

$2 \frac{1}{2}$ in. $\mathrm{Hg}$

6. Seal steam pressure

2 psig

7. Turbine operating time, before test

$8900 \mathrm{hr}$

C. Specific Procedure for First-phase Tests

With the vapor recovery system in operation and all recovered air and vapor being directed to the vent condenser, the following procedure 
was carried out:

1. Pressures were read and recorded at $2-\mathrm{hr}$ intervals for $72 \mathrm{hr}$ at

a. all seal dry air chambers,

b. all seal collection chambers (vacuum),

c. main blower outlet and inlet,

d. vent condenser, and

e. seal steam header.

2. Temperatures were automatically recorded at $10-$ min intervals for $72 \mathrm{hr}$ at those points required to determine the temperatures of
a. dry air supplied to seals,
b. the steam-air mixture returning from the seals,
c. the vent condenser air at inlet, air at outlet and cooling water,
d. the air cooler Freon and air at outlet, and
e. the makeup air in and out of desiccators.

3. Moisture content of the dry air was automatically sampled and continuously recorded for $24 \mathrm{hr}$ at each of the following points:
a. outlet of the main system blower (dry air to seals);
b. outlet of the recovered air desiccators; and
c. outlet of the makeup air desiccators.

The air leaving the "recovered air" Freon air cooler was sampled periodically.

4. Upon termination of the $72-\mathrm{hr}$ test period, all data was analyzed and averaged.

D. Specific Procedure for Second-phase Tests

1. With the turbine and vapor recovery system operating normally, test apparatus was introduced to prepare the recovery system for flow tests as follows: 
a. Shifted all dry air rotometers into the dry air lines by means of the bypass valves provided.

b. Increased dry air supply pressure to 10 in. of $\mathrm{H}_{2} \mathrm{O}$ (or higher when required). The valves at the dry air rotometer inlets were used to obtain the proper normal dry air operating pressure in the seal gland.

c. Closed valve on dry air supply to turbine casing joint seal.

d. Started blower and coolants in test fluid recovery loop.

e. Selected seal to be tested and selected the proper recovered air rotometer to achieve as near a full-scale reading as possible.

f. Directed the recovered air and steam from the vacuum gland of the seal being tested to the test fluid recovery loop by means of the valves provided.

g. Regulated the pressure in the seal vacuum gland to the desired pressure (Section VI-A) by use of the valve on the outlet of the recovered air rotometer.

h. Recorded the following data:

(1) moisture, pressure and temperature of the dry air supply,

(2) dry air rotometer flow, pressure and temperature,

(3) recovered air rotometer flow, pressure and temperature,

(4) time required to fill 2-1iter graduate with recovered water for flow rate determination, and

(5) makeup and recovered air flow moistures, pressures and temperatures.

2. Using the above procedures, each seal was tested individually. When the turbine shaft seals were tested, the vacuum gland pressures at the high and low end we re regulated to the same pressure to prevent interflow between seals via the casing joint groove.

3. Both turbine shaft seals were tested simultaneously to check the individual seal tests. 
4. All seals were tested simultaneously by venting all vacuum glands to the test apparatus. Individual seal pressures were regulated to operating average values by using valves to throttle individual flows, and increasing main supply pressure to achieve required head. 
VII. TEST RESULTS AND OBSERVATIONS

\section{A. Seal Pressures}

As part of the first-phase tests, the seal air pressures were recorded during the first four days of operation. The high, low, and average readings are listed in Table 1.

Table 1

DATA SUMMARY

\section{Seal Pressures}

A. Blower Pressure

1. Outlet

2. Inlet

B. Dry Air Glands of Seals:

1. Turbine High-pressure End

2. Turbine Low-pressure End

3. Feed Pumps Seals

4. Throttle Valve Stem

5. Inlet Valve Stem

6. Bypass Valve Stem

C. Vent Condenser Vacuum

D. Recovered Air Glands of Seals:

1. Turbine High-pressure End

2. Turbine Low-pressure End

3. Feed Pump Seals

4. Throttle Valve Stem

5. Inlet Valve Stem

6. Bypass Valve Stem

E. Seal Steam

\begin{tabular}{ccc} 
High & Low & Average of \\
Pressure, & Pressure, & 30 Readings, \\
in. W.G. & in. W.G. & in. W.G. \\
\hline
\end{tabular}

$\begin{array}{rrr}8.0 & 6.5 & 7.1 \\ -24.0 & -21.5 & -23.0\end{array}$

7.3

5.8

6.6

7.0

5.8

6.4

4.0

2.7

3.1

7.8

5.9

7.0

7.6

6.5

7.0

3.7

2.7

3.1

$-7.0$

$-6.5$

$-6.9$

$-5.0$

$-3.7$

$-4.3$

$-4.6$

$-4.2$

$-4.4$

$-6.9$

$-6.4$

$-6.9$

$-5.2$

$-4.5$

$-4.7$

1.6

$-0.5$

$-1.0$

$-7.0$

$-4.5$

$-5.7$

2 psi

2 psi

2 psi 
Figure 12 is a plot of the turbine and pump seal pressures. As can be seen, variations of blower speed cause the supply air pressure to deviate with an amplitude of one-inch water gauge. The gland pressures followed the fluctuation of the supply. As the gauges were not read simultaneously, the plot does not give an accurate indication of pressure drops in the line. The line loss between the blower and dry air gland of the turbine seals appears to be on the order of $\frac{1}{2}$ in. W.G.; however, there is a relatively large pressure drop between the blower and the feed pump seal. The bypass valve seal is supplied by the same line and exhibits a similar drop. The throttle and inlet valve seals operate very close to blower pressure. These seals are supplied by $\frac{3}{4}-$ in. pipe taps off the main line supply to the turbine seals. This indicates that the line drop to the turbine seals occurs in the pipe branches leading to the individual seals.

The pressure drop in the recovered air line between the turbine glands and the vent condenser tank was 2.5 in. W.G., as a result of the large volume of seal steam returning with the air. The line drop in the $\frac{3}{4}-$ in. recovered air line from the inlet valve seal was $3.5 \mathrm{in}$. W.G. more than that of the adjacent throttle valve seal. Since the lines are similar, the pressure drop difference is attributed to higher seal steam flow rates from the inlet valve stem seal. It was observed that the inlet valve seal was operating improperly early in the test. Seal steam condensate seeping into the dry air gland manometer gave further evidence of seal wear.

Improper drainage of the bypass valve seal vacuum line caused line condensate to drain into the manometer tubing. When the tap valve was closed, this condensate was forced to return to the vent condenser. However, this is not a desirable design characteristic since it could lead to back leakage via the dry air gland. The line should be corrected to drain to the vent condenser.

\section{B. System Temperatures}

High, low and average temperatures are recorded in Table 2. The dry air supplied to the seals was observed to be heated enroute to the seals by the pipe walls. The pipes receive heat both from the atmospheric air and by conduction from the seal housings. The steam seal housings operated at temperatures approaching seal steam temperature $\left(336^{\circ} \mathrm{F}\right)$. The temperature of the air in the seal was not amenable to direct meas urement, but from inlet conditions, seal temperature and observed flow rates, it would appear to be of the order of $200^{\circ} \mathrm{F}$ in the turbine and bypass valve seals, $80^{\circ} \mathrm{F}$ in the pump seals, and $300^{\circ} \mathrm{F}$ in the inlet and throttle valve seals.

The steam-air mixture averaged $197^{\circ} \mathrm{F}$ at the inlet to the vent condenser. The recovered air temperatures were in the expected range considering cooling water and Freon temperatures. 


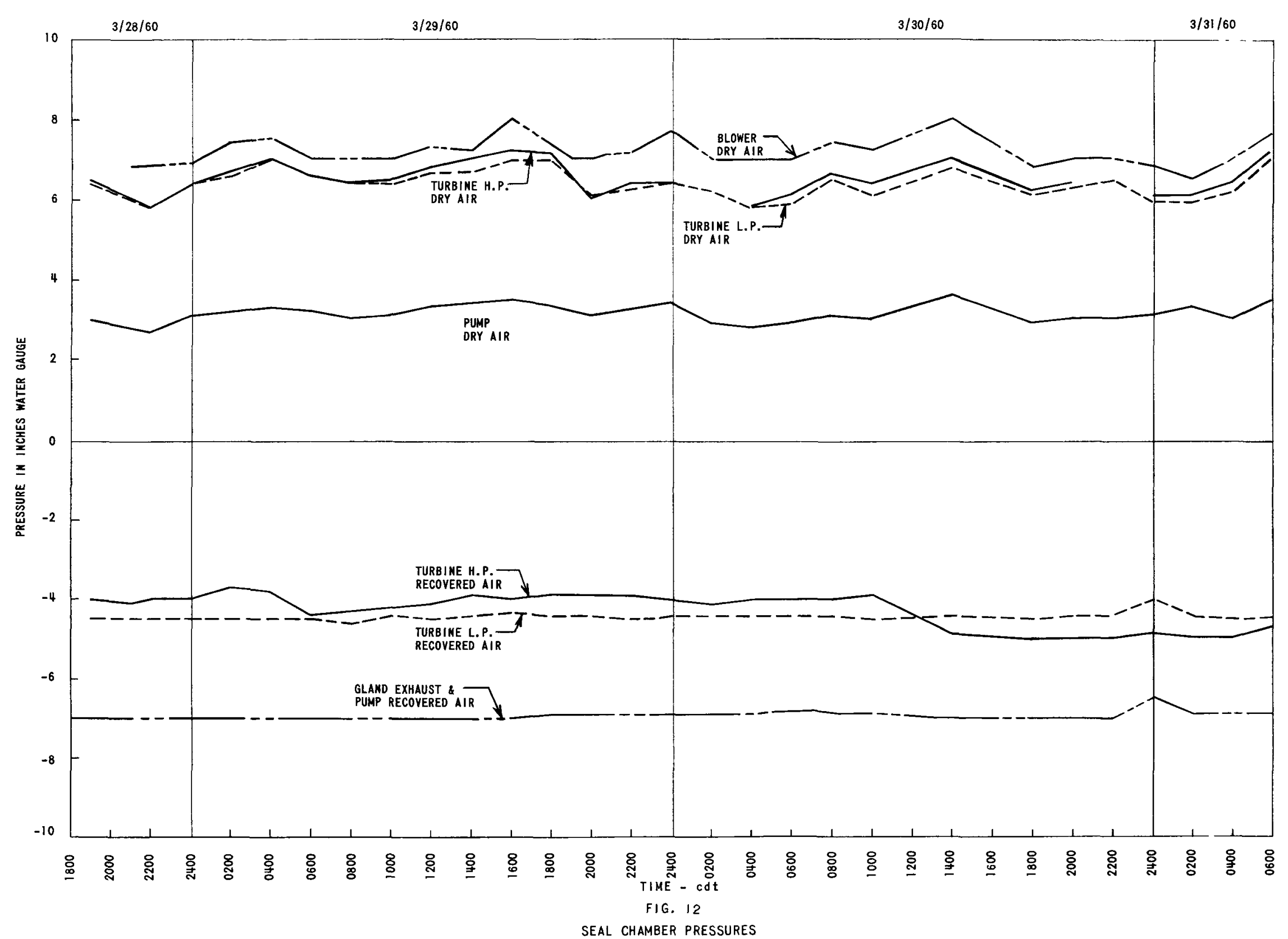


Table 2

SYSTEM TEMPERATURES

$\frac{\text { Temperatures, }{ }^{\circ} \mathrm{F}}{\text { High Low Average }}$

A. Dry Air Supplied to Seals

1. At blower discharge

103

77

83

2. Turbine seals, throttle and inlet valve seals

100

91

95

3. Feed pump and bypass valve seals

82

77

80

B. Steam-Air Mixture Returning from Seals

1. Turbine high-pressure end

210

197

200

2. Turbine low-pressure end

193

168

181

3. Feed pump seals

70

70

70

4. Throttle valve stem

322

306

315

5. Inlet valve stem

318

302

310

6. Bypass valve stem

202

174

200

C. Recovered Air-Vapor Mixture

1. Steam-air entering vent condenser

200

192

197

2. Vent condenser cooling water

76

43

64

3. Recovered air entering Freon cooler

98

75

84

4. Freon temperature

51

46

5. Recovered air entering desiccator

71

63

67

6. Recovered air leaving desiccator

D. Makeup Air

1. Air entering Freon cooler (ambient)

$\sim 90$

2. Freon temperature

45

$\sim 80$

$\sim 88$

3. Air entering makeup desiccator

60

32

35

4. Air leaving makeup desiccator

150

42

55

82

118 
Makeup air was drawn from the atmosphere. Ambient temperatures in the containment shell vary between $80^{\circ} \mathrm{F}$ and $90^{\circ} \mathrm{F}$ during plant operation. The $35^{\circ} \mathrm{F}$ Freon cooled the air to $55^{\circ} \mathrm{F}$ before entering the makeup desiccators. A plot of the temperatures leaving the makeup desiccators indicated that these desiccators were not cooling by radiation as per design. Figure 13 illustrates a typical plot of air temperature at the exit of the makeup desiccators. The effect of this is discussed further under "Moisture."

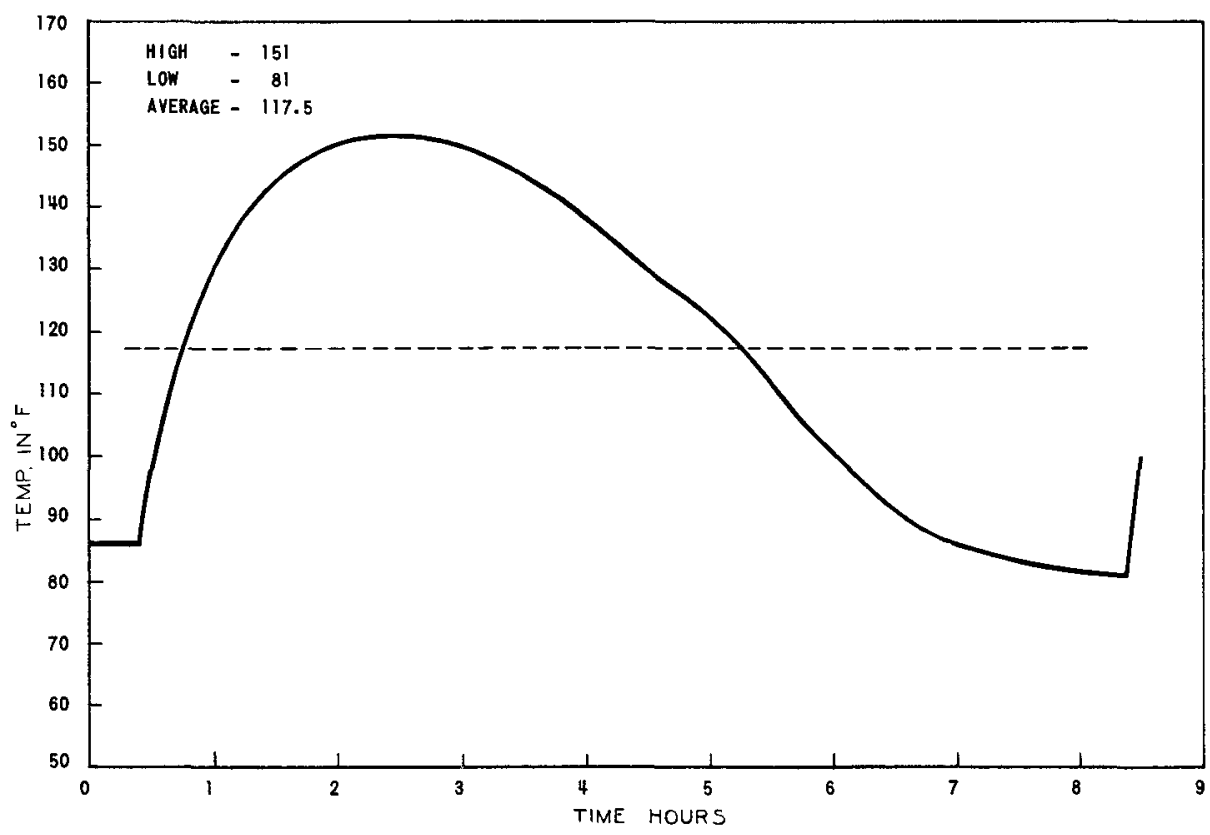

FIG. I3

TYPICAL PLOT OF AIR TEMPERATURE AFTER MAKEUP AIR DESICCATOR

\section{Air Moisture}

The moisture content of the air at points of design interest are tabulated in Table 3. Water vapor is indicated both in volumetric parts per million and by the ratio of "lb of water" per "million cubic ft of dry air at $60^{\circ} \mathrm{F} . "$

The "consolidated" moisture monitor was used to record the moisture in air from: (1) exit of makeup desiccator; (2) exit of recovered air desiccator; and (3) blower discharge. A composite plot of a typical 8-hr cycle is illustrated in Fig. 14. The major contribution of moisture to the "dry" air supplied to the seals is from the makeup air side, in the form of atmospheric $\mathrm{H}_{2} \mathrm{O}$. Only a very small per cent of reactor water is contributed from the desiccators of the recovered air side. It is apparent that the makeup side is less effective than the recovered air side. 
Table 3

AIR MOISTURE

\begin{tabular}{cc}
$\begin{array}{c}\text { Water Vapor, } \\
\text { ppm by volume }\end{array}$ & $\begin{array}{c}\text { Water per } \\
\text { High }\end{array}$ \\
\hline
\end{tabular}

A. Recovered Air Moisture

1. Air entering vent condenser

2. Air entering Freon cooler

50,000

30,000

40,000

183,000

3. Air entering desiccator

22,000

19,000

20,000

2,000

1,000

4. Air leaving desiccator

30

20

25

1.3

B. Makeup Air Moisture

1. Air entering Freon cooler

2. Air entering desiccator

3. Air leaving desiccator

$$
\text { (see Fig. 14) }
$$

16,000

9,000

$\sim 20,000$

12,000

1,000

610

1,700

40

490

25

C. Air to seals (mixture of A and B)

820

30

230

12

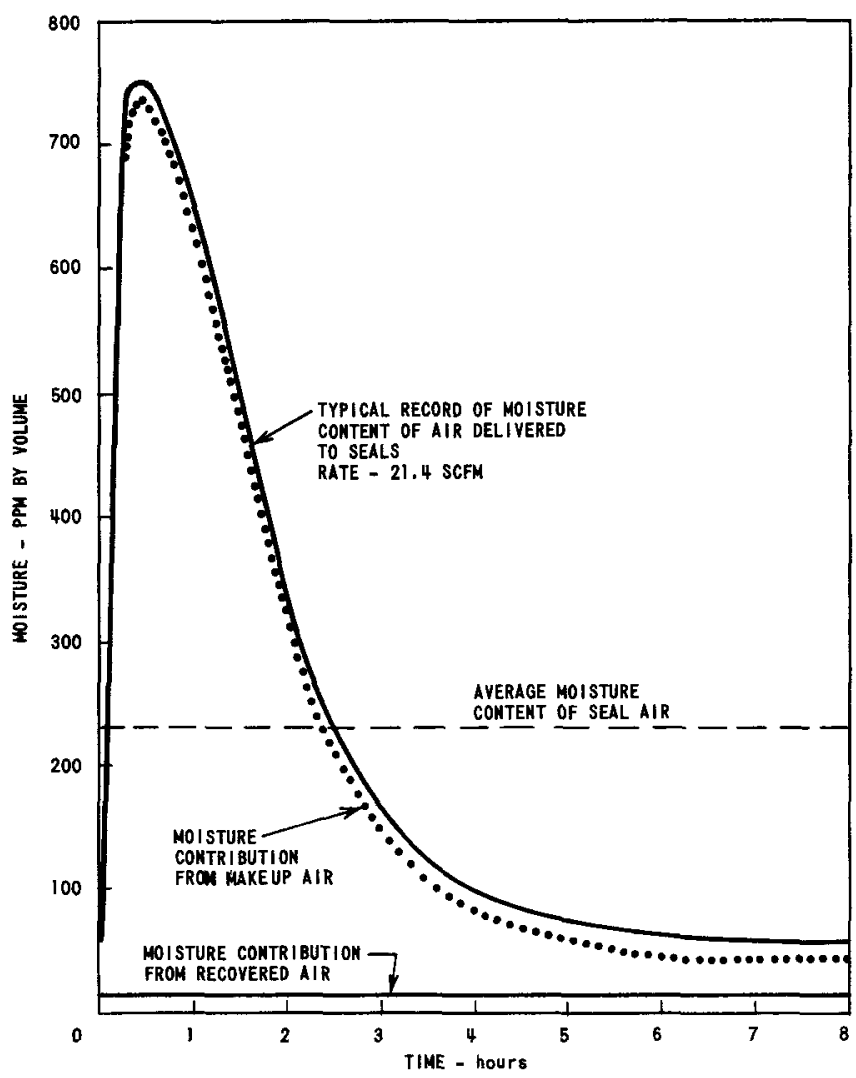

F1G. 14

DRY AIR BARRIER MOISTURE 
The desiccator systems cycle from the spent alumina beds to the recharged fresh beds on an $8-\mathrm{hr}$ period. During the period, the spent recovered air bed is regenerated by blowing air through a closed regeneration loop. Air from a sealed blower is heated electrically and forced through the bed. The heated bed gives up its stored moisture to the air. After leaving the bed, the air is chilled in a water-cooled heat exchanger and the entrained water vapor is condensed on the tubes. The condensate drains to the vent condenser tank and the air is drawn to the blowe $x$ for recycle. After four hours the heaters are de-energized, and the blower continues to circulate, cooling the bed for the remaining four hours.

During the same 8-hr period, the spent makeup air desiccator is regenerated as follows: the makeup bed is heated by electrical heaters in the alumina bed. A blower forces atmospheric air through the bed. The bed releases its moisture to the air and the air returns to the atmosphere. Both the blower and the heaters are de-energized after four hours. For the remaining four hours the bed is left to cool by external air convection and radiation.

During the cooling period of the regeneration cycle, the recovered air bed has been cooled to less than $80^{\circ} \mathrm{F}$, but the makeup air bed has only cooled to $200^{\circ} \mathrm{F}$. Consequently, when the regenerated beds are shifted into operation, the makeup bed is less effective than the recovered air bed until the cool makeup air lowers the bed temperature.

The similarity of Figs. 13 and 14 readily indicates the relationship of bed effectiveness to bed temperature. In analyzing Figs. 13 and 14, the slow response of the instruments must be taken into account. The shift of the peak to the right of zero time indicates the magnitude of the lag.

The air temperatures were recorded by insulated thermocouples on the surface of the air lines. The moisture monitor drew its sample at a rate of $20 \mathrm{cc} / \mathrm{min}$ through $4 \mathrm{ft}$ of $\frac{1}{4}-i n$. stainless steel tubing.

During the test period, the readings of the Consolidated instrument were checked by means of an "Alnor Dew Pointer." The "Dew Pointer" was also used to sample ambient air and air at the Freon cooler exits. Moisture measurements of air leaving the Freon coolers indicated that this air is saturated. Moisture at these points is therefore indicated by the air temperature records.

\section{Air Flow}

The data of Table 4 and Figs. 15, 16 and 17 are a summary of more than 80 individual seal tests. The tests were conducted at intervals over a two-month period to observe the influence of general plant parameters. 
Table 4

AIR FLOW

A. With Design Pressures at Seals

(i.e., +6 in. W.G. at dry gland and -6 in. W.G. at recovery gland)

1. Air Flow to Seals

a. Turbine, high-pressure end

Measured

ANL-5607

Flow

Design Flow

b. Turbine, low-pressure end

(scfm)

(scfm)

c. Feed pump seals

9.0

7.5

d. Throttle valve, inlet valve and bypass valve

3.3

7.5

0.1

6.2

$\overline{21.6}$

0.7

21.9

2. Air Flow Recovered
a. Turbine, high-pressure end
5.5
3.7
b. Turbine, low-pressure end
5.0
3.7
c. Feed pump seals
2.0
3.1
d. Throttle valve, inlet valve and bypass valve
$\sim 0.08$
0.5
$\overline{12.6}$
11.0

3. Air Lost to Containment Atmosphere
a. Turbine, high-pressure end
3.7
3.8
b. Turbine, low-pressure end
4.0
3.8
c. Feed pump seals
1.3
3.1
d. Throttle valve, inlet valve and bypass valve
$\sim \frac{0.02}{9.0}$
0.2
10.9

B. With "Average" Measured Operating Pressures in Seal Glands 1. Air Flow to Seals

Measured Flow

a. Turbine, high-pressure end $(\mathrm{scfm})$

\section{(+6.6 in. pressure \& -4.3 in. vacuum)}

9.2

b. Turbine, low-pressure end

$(+6.4$ in. pressure \& -4.4 in, vacuum)

c. Feed pump seals $\left(+3.1\right.$ in. pressure \& -6.9 in. vacuum) $\frac{2.7}{20.8}$ 
Table 4 (Cont'd.)

Measured Flow (scfm)

2. Air Flow Recovered

a. Turbine, high-pressure end

(10.9 in. $\mathrm{H}_{2} \mathrm{O}$ pressure drop through seal)

b. Turbine, low-pressure end (10.8 in. $\mathrm{H}_{2} \mathrm{O}$ drop)

c. Feed pump seals (10.0 in. $\mathrm{H}_{2} \mathrm{O}$ drop)

11.7

3. Air Lost to Containment Atmosphere

a. Turbine, high-pressure end (6.6-in. drop)

b. Turbine, low-pressure end (6.4-in. drop)

4.2

C. Feed pump seals (3.1-in. drop)

0.9

9.1

4. $\%$ Lost $=9.1 / 20.8=43.7 \%$

$\%$ Recovered $=11.7 / 20.8=56.3 \%$

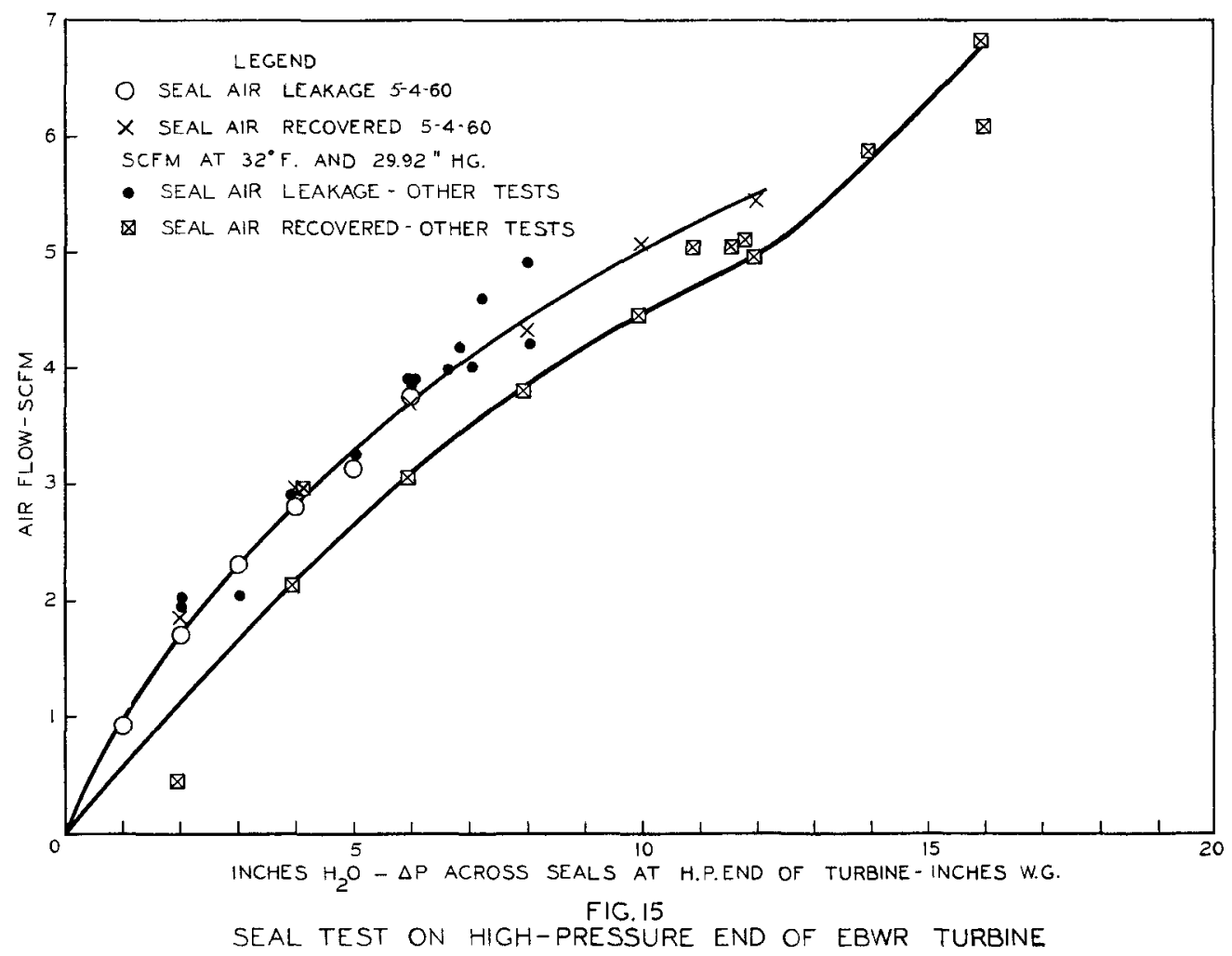



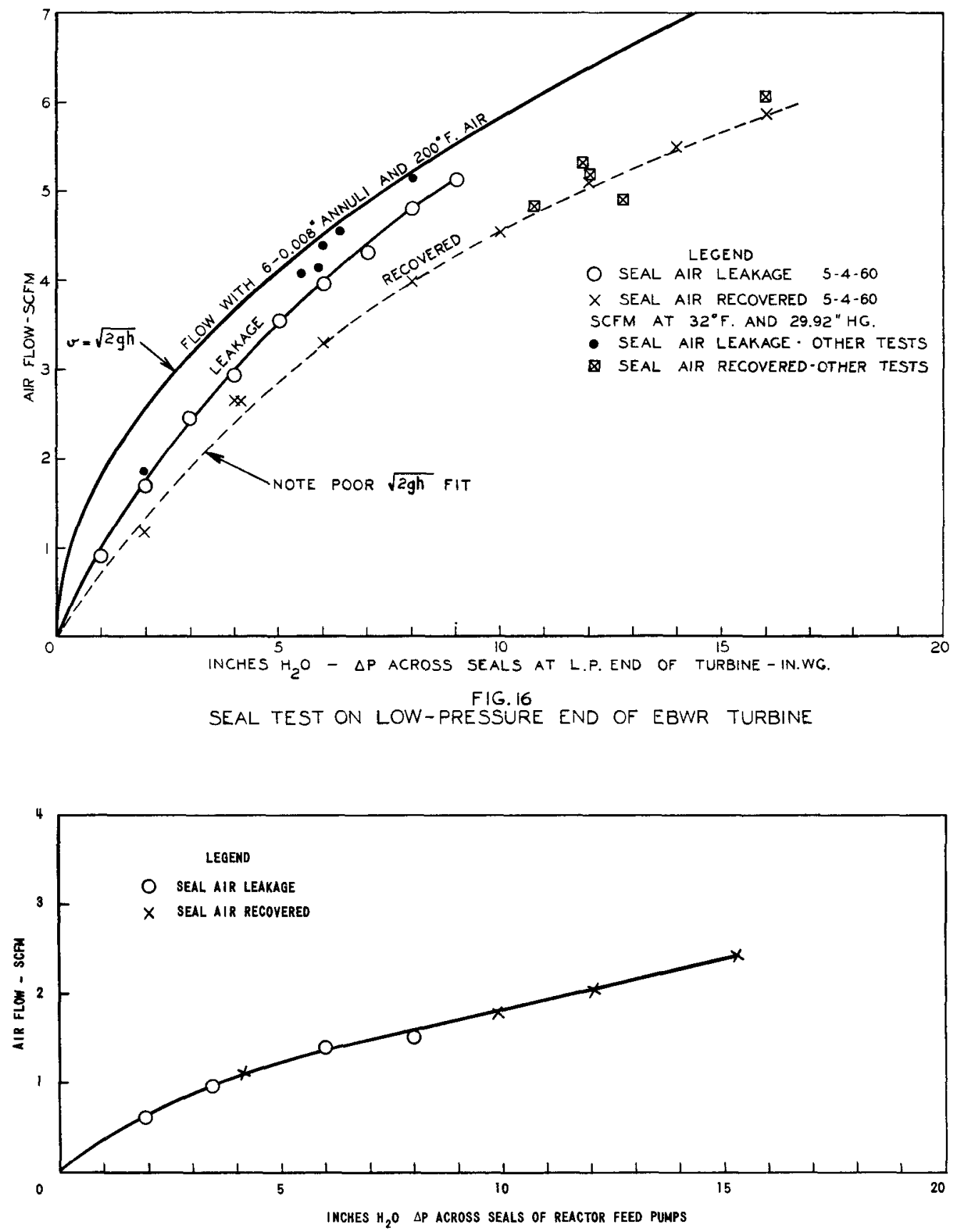

FIG. 17

SEAL TEST OF FEED PUMP SEAL

Turbine seal flow rates were not found to be significantly affected by turbine load; however, the effect of turbine shaft rotation is observable. The turbine inlet valve stem seal flows were slightly affected by stem position. It was found that simultaneous flow readings were necessary to obtain good data correlation of flow rates to observed pressure drops. 
1. Flow Rates with "Design" Seal Pressures

All supply air was directed through the seal rotometers, and the pressure at each seal was adjusted to +6 in. water gauge. To measure the recovered air flow of the individual seal, the recovered air was directed to the test recovery system and the seal vacuum gland pressure was adjusted to -6 in. water gauge.

Table 4-A lists the flow of air supplied to each seal, the air recovered, and the dry air lost to the reactor containment atmosphere. The measured flows listed have been corrected to standard conditions $\left(32^{\circ} \mathrm{F}\right.$ at $\left.29.92 \mathrm{in} . \mathrm{Hg}\right)$. The design flow rates listed are those presented.(2)

2. Flow Rates with "Operating Average" Seal Pressures

The operating seal pressures measured during the firstphase tests were averaged to obtain seal pressures for "operating" flow rate measurements. The seal pressures were adjusted to the operating averages and the individual seals were tested. The observed flow rates are tabulated in Table 4-B. Data on valve seals are not tabulated because air flows were always much less than $0.1 \mathrm{scfm}$.

\section{Seal Characteristics}

The characteristics of the turbine seals are presented in Figs. 15 and 16. Feed pump seal characteristics are plotted in Fig. 17. The plots were obtained by varying seal pressures in 1 in. water gauge increments from a) 1 in. W.G. to 9 in. W.G. in the dry air gland, and b) -1 in. W.G. to -9 in. W.G. in the recovered air gland. The pressure drop through the six-stage labyrinth to atmosphere was related to leakage flow. The pressure drop through the 12 -stage labyrinth was related to recovered air flow.

The seal at the high-pressure end of the turbine has coincident curves for both 6-stage and 12 -stage labyrinths. Figure 4 shows the original shop clearances in the labyrinths. Simple flow theory indicates that with such clearances the coincidence of curves is not unreasonable.

The curves of the low-pressure end seal, Fig. 16, are separated, as would be expected from the similarity of clearances.

4. Labyrinth Seal, Flow Model, and Derivation of Correlation Equation

Experimental turbine seal flow rates could not be correlated by simple "orifices in series" flow equations (see Fig. 18). An attempt has been made to establish a more realistic flow model (see Fig. 19) and derive these from a flow equation as follows: 


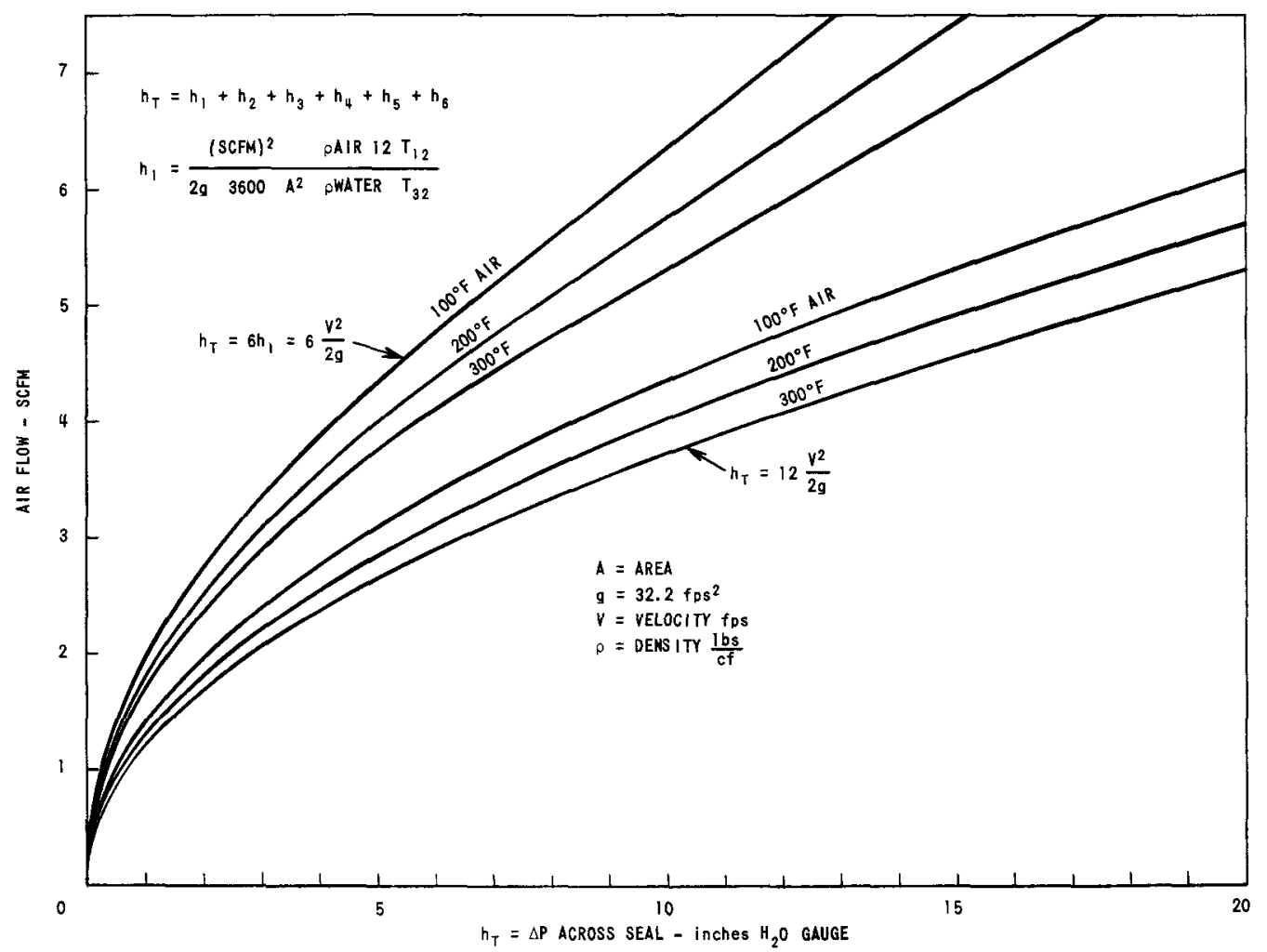

FIG. 18

IDEAL FLOW THROUGH 6-STAGE ANO 12-STAGE LABYRINTH AIR SEALS WITH .OO8" ANNULAR ORIFICES

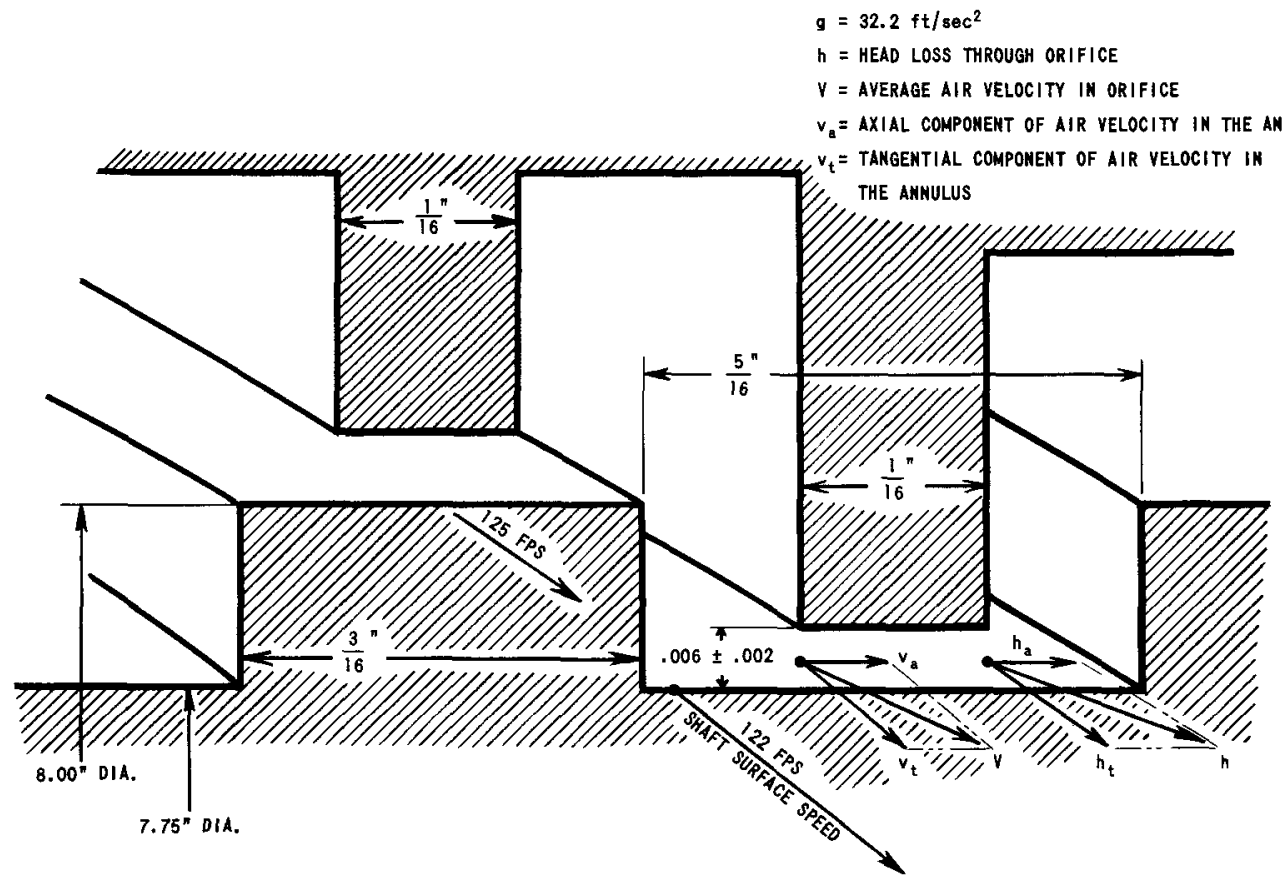

FIG. 19

LABYRINTH SEAL, FLOW MODEL 
(1) $\mathrm{V}=\sqrt{\mathrm{v}_{\mathrm{t}}^{2}+\mathrm{v}_{\mathrm{a}}^{2}}$

(2) $h=\sqrt{h_{t}^{2}+h_{a}^{2}}$

(3) $\mathrm{h}=\mathrm{V}^{2} / 2 \mathrm{~g}$

(4) $\sqrt{h_{t}^{2}+h_{a}^{2}}=(1 / 2 g)\left(v_{t}^{2}+v_{a}^{2}\right)$

(5) $h_{t}^{2}+h_{a}^{2}=\frac{1}{(2 g)^{2}}\left(v_{t}^{4}+2 v_{t}^{2} v_{a}^{2}+v_{a}^{4}\right)$

(6) $h_{t}^{2}+h_{a}^{2}=\frac{v_{t}^{4}}{4 g^{2}}+\frac{2 v_{t}^{2} v_{a}^{2}}{4 g^{2}}+\frac{v_{a}^{4}}{4 g^{2}}$

But for practical purposes, the axial inlet velocity before the annulus is zero, the axial velocity after the annulus is zero, and none of the axial velocity head in the annulus is recovered. Since the tangential velocity is induced by shaft rotation it is not unreasonable to assume that it is near constant, both in and out of the orifice.

$$
\text { (7) } h_{t}^{2}=\frac{V_{t}^{4}}{4 g^{2}} \cong \text { a constant. }
$$

Then the head loss is equal to

(8) $\Delta \mathrm{h}_{\mathrm{a}}^{2}=\frac{\mathrm{v}_{\mathrm{a}}^{4}}{4 \mathrm{~g}^{2}}+\frac{2 \mathrm{v}_{\mathrm{t}}^{2} \mathrm{v}_{\mathrm{a}}^{2}}{4 \mathrm{~g}^{2}}$

or

(9) $\Delta \mathrm{h}_{\mathrm{a}}=\frac{\mathrm{v}_{\mathrm{a}}}{2 \mathrm{~g}} \sqrt{\mathrm{v}_{\mathrm{a}}^{2}+2 \mathrm{v}_{\mathrm{t}}^{2}}$.

A good fit is achieved with $v_{t}=(1 / 4)($ shaft surface speed)(see Fig. 20$)$. 


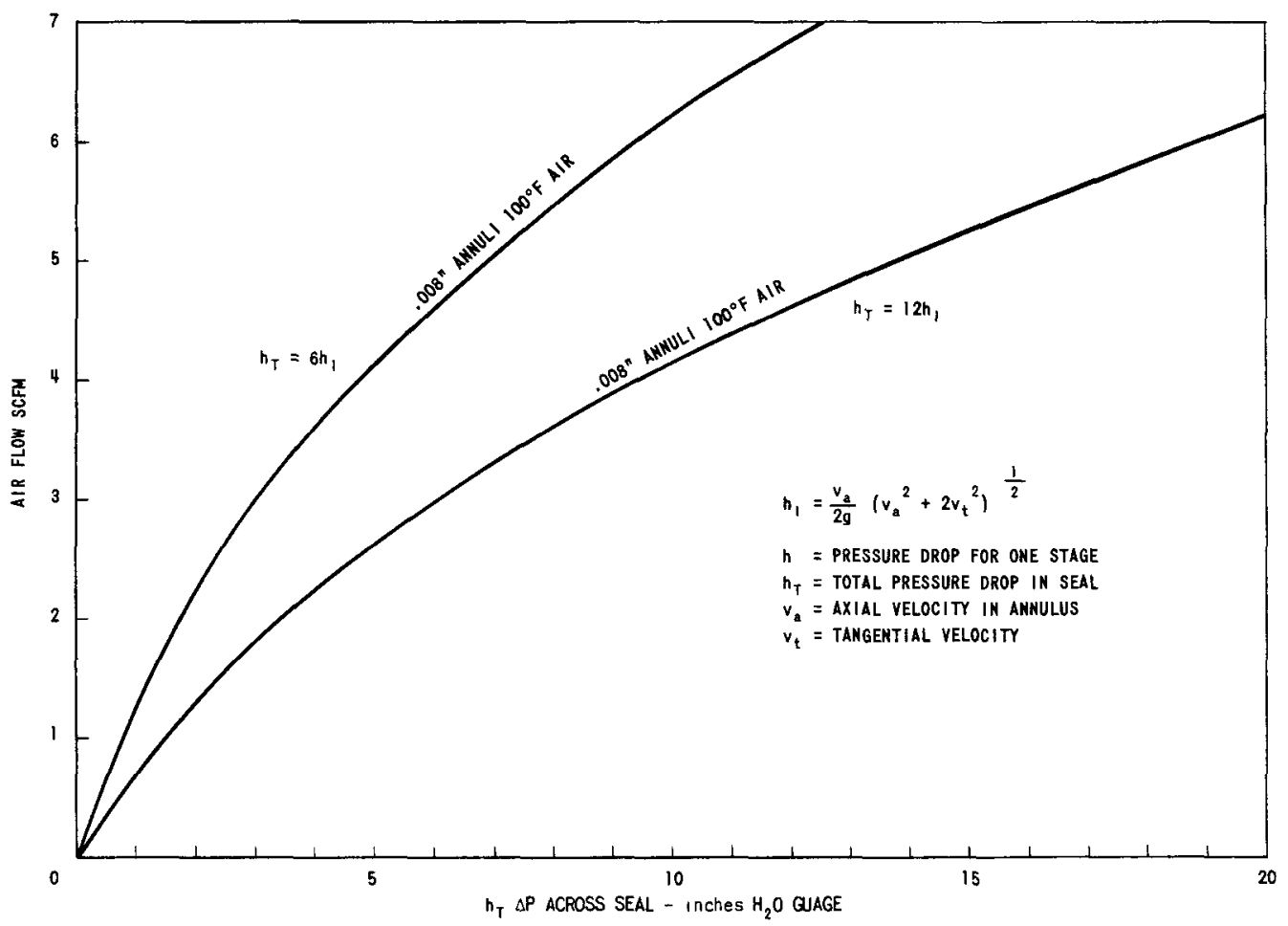

FIG. 20

CORRELATION FOR TURBINE ROTATING LABYRINTH SEALS

"TWO COMPONENT FLOW" MODEL

\section{E. Seal Steam and Seal Water Flows}

The seal steam flow entering the recovered air vacuum glands remained essentially constant throughout the test. Both high-pressure and low-pressure end flow rates were equal. Seal steam pressure was automatically controlled to a constant 2 psi and the labyrinths on both ends have 12 stages; hence, the equal flow rates observed infer equal labyrinth clearances at both ends. The flow rates to the recovery system were higher than the design estimates, probably indicating labyrinth wear. This wear was noted at the 3,900-hr turbine seal inspection. The turbine has operated $5,000 \mathrm{hr}$ since that time. The values of Table 5 are the averages of 30 "individual" seal measurements, and checked by 15 "multi" seal tests. During testing, deviations from this average were observed to be caused by holdup in the water seal loops of the drainage lines, and by the measurement technique. From the data, the actual flow is judged to be very stable. The seal steam temperature averaged $336^{\circ} \mathrm{F}$ at $16 \mathrm{psia}$. The heat rate of the vent condenser at $120 \mathrm{lb} / \mathrm{hr}$ is $125,000 \mathrm{Btu} / \mathrm{hr}$, which is one-half its rated load.

The seal water flow of the feed pumps is very close to design expectations, indicating proper seal operation. Flow rate was relatively small and leakage collection extended into hourly periods. 
Table 5

SEAL STEAM AND SEAL WATER FLOWS*

\begin{tabular}{cl}
$\begin{array}{c}\text { Measurement, } \\
\mathrm{lb} / \mathrm{min}\end{array}$ & $\begin{array}{c}\text { Design, } \\
\mathrm{lb} / \mathrm{min}\end{array}$ \\
\hline
\end{tabular}
A. Turbine, high-pressure end
1.07
0.55
B. Turbine, low-pressure end
1.08
0.55
C. Feed pumps
0.04
0.043
D. Throttle, inlet and bypass valves
$\frac{0.3}{2.49}$
$\frac{0.13}{1.27}$

* These flows are proportional to the pressure of the seal steam (or water). Seal steam pressure was 2 psig during all tests. The small variations in seal air gland vacuum therefore had negligible effect upon the seal steam flow rate. Further, the flows are not leakages, since they are all collected in the vapor recovery system.

Flow rates from valve seals were greater than design expectations; however, the low flow rates and line holdup precluded a high degree of accuracy in these measurements. No rearrangements were made to improve accuracy since flows were a negligible per cent of total.

\section{F. Leakage and Contamination}

From the above data, the primary system moisture out-leakage rate and the atmospheric air moisture in-leakage rates were calculated. To illustrate the leak rates that would occur, it has been assumed that the primary system is filled with $\mathrm{D}_{2} \mathrm{O}$. The air flows assumed for these calculations were $11.7 \mathrm{scfm}$ recovered, $9.1 \mathrm{scfm}$ lost, and $9.1 \mathrm{scfm}$ makeup. The total flow supplied to seals is $72,000 \mathrm{lb} /$ month.

1. With "best" vapor recovery system operation:
a. $\mathrm{D}_{2} \mathrm{O}$ in air to seals
14.1 ppm by volume
b. $\mathrm{H}_{2} \mathrm{O}$ in air to seals
$11.5 \mathrm{ppm}$ by volume
c. $\mathrm{D}_{2} \mathrm{O}$ leakage to containment shell
$0.27 \mathrm{lb} \mathrm{D}_{2} \mathrm{O} /$ month
d. $\mathrm{H}_{2} \mathrm{O}$ contamination of primary $\mathrm{D}_{2} \mathrm{O}$
$0.29 \mathrm{lb} \mathrm{H} \mathrm{H}_{2} \mathrm{O} /$ month 
This condition could have been achieved if the makeup air desiccators were regenerated by a system similar to that of the recovered air desiccators. It was assumed that the makeup air desiccators were as effective as those of the recovered air.

2. With the actual observed normal operation:
a. $\mathrm{D}_{2} \mathrm{O}$ in air to seals
$14.1 \mathrm{ppm}$
b. $\mathrm{H}_{2} \mathrm{O}$ in air to seals
$134 \mathrm{ppm}$
c. $\mathrm{D}_{2} \mathrm{O}$ leakage to containment shell
$0.27 \mathrm{lb} \mathrm{D}_{2} \mathrm{O} /$ month
d. $\mathrm{H}_{2} \mathrm{O}$ contamination of $\mathrm{D}_{2} \mathrm{O}$
$5.5 \mathrm{lb} \mathrm{H} \mathrm{H}_{2} \mathrm{O} /$ month

3. With observed abnormal operation:
a. $\mathrm{D}_{2} \mathrm{O}$ in air to seals
$3540 \mathrm{ppm}$
b. $\mathrm{H}_{2} \mathrm{O}$ in air to seals
$216 \mathrm{ppm}$
c. $D_{2} \mathrm{O}$ leakage to containment
$69 \mathrm{lb} \mathrm{D}_{2} \mathrm{O} /$ month
d. $\mathrm{H}_{2} \mathrm{O}$ contamination of $\mathrm{D}_{2} \mathrm{O}$
$5.5 \mathrm{lb} \mathrm{H}_{2} \mathrm{O} /$ month

This considers the makeup desiccators operating normally and the recovered air desiccators inoperative, as observed in Section VII-G.

\section{G. Observed Abnormalities}

1. Failure of Recovered Air Reactivation Loop Blower

During the first week of testing it was observed that the dry air supplied to the seals was clearly higher in moisture content than specified by design. The dew point of the main dry air supply to seals was $+27^{\circ} \mathrm{F}$ to $+35^{\circ} \mathrm{F}$, and averaged $+33^{\circ} \mathrm{F}(6300 \mathrm{ppm}$ by volume $)$ over a $24-\mathrm{hr}$ period. The difficulty was traced to a motor burnout of the subject blower. Note that this blower is a sealed unit without rpm indication or power alarm. The only indication of failure was the low temperature of the desiccant bed being reactivated. As a consequence of the blower failure, the alumina desiccant became saturated with moisture. Upon repair of the blower, one week of normal $8-\mathrm{hr}$ cycle reactivation was required to dry the beds.

\section{Valve and Pump Seals}

The inlet valve and bypass valve seal chamber pressures did not correspond to design. However, since sufficient pressure was available for an effective dry air barrier, this abnormality did not result in abnormal leakage. The feed pump seal and bypass valve seal low 
pressures are attributed to a pipe restriction. The low pressure of the inlet valve recovercd air/steam chamber is attributed to a high seal steam flow rate caused by seal wear. None of these abnormalities were corrected during the test period.

\section{Hydrostatic Testing}

During hydrostatic tests on the reactor vessel (which is normal practice after reactor pressure vessel modifications), it was observed that water was forced into the dry air lines through the throttle valve and bypass valve seals. This occurred because (a) the vapor recovery system was normally not operating at such time and (b) the bypass valve vacuum line was not properly pitched to drain the chamber to the vent condenser tank. This occurrence was partially overcome by operating the vapor recovery system during hydrostatic tests. The line pitch was not corrected during the test period.

\section{Makeup Air Desiccator Cooling}

The design of the reactivation loop for the makeup air desiccators led to a prediction that the refreshed bed would cool to operating temperature by radiation. It was observed that radiation did not completely cool the bed. The effects of this are presented in Section VII-C. An improved cycle could be achieved by providing post reactivation cooling of these beds.

\section{Seal Air Pressure Controller}

During the test it was found that the seal dry air pressure controller could not be operated in the "automatic" position without excessive hunting. Satisfactory operation was obtained by use of the "manual" setting allowing manual regulation of the makeup air control valve. 


\section{CONCLUSIONS}

The vapor recovery system has operated in reasonable accord with design expectations. All associated seal leakages were collected and recovered. Effective dry air barriers were maintained at all system seals. Air and vapor flows were found to be in close accord with design values. All this was accomplished in spite of the fact that some valve seal pressures differed considerably from design and the makeup desiccators were not cooled fully after regeneration. Even with such a severe abnormal condition as a complete failure of the recovered air desiccators, the system was able to hold leakage to a tolerable level.

It was found that the heat exchange and desiccation equipment is capable of handling greater leak rates than experienced under normal operation. This results from the system design to recover vapor from air ejectors during condenser-hogging operations and from the assumed design parameter of $100^{\circ} \mathrm{F}$ vent condenser cooling water.

Extrapolating operating experience to a nonexperimental power plant, it is concluded that substitution of two half-capacity units would be preferable to the one installed. This would give the overcapacity needed for hogging and possible seal failure plus the ability to make recovery system repairs with the plant in operation.

From measured air flows it appears that the turbine shaft air labyrinths have very little wear. The turbine seal steam flows were twice the design rate, indicating labyrinth wear of the order of 0.005 in. This steam labyrinth wear was noted, but not measured, at the last turbine overhaul. Inlet valve seal pressures indicate seal wear sufficient to warrant replacement. The feed pump seal appears to be in excellent condition.

Maintenance of "dry" seal air is the major factor required for low $\mathrm{D}_{2} \mathrm{O}$ leak rates. With good dry air control, seal labyrinth tolerances could be relaxed. The recovery system is capable of maintaining the $\mathrm{D}_{2} \mathrm{O}$ leakage from its associated seals to less than one pound per month. It could also be made capable of holding the atmospheric vapor in-leakage to less than one pound per month. With system redesign to "heat-less" type desiccators, leakage could be reduced to the order of one pound per year. It should be noted that these low leak rates do not represent total system leakages, since all seals are not connected there-to and there are other leakages not amenable to recovery system application.(2) 


\section{RECOMMENDATIONS}

The existing system should be modified to (1) drain air lines properly; (2) remove obstruction in the feed pump dryair line; (3) change makeup air desiccator regeneration to cool bed properly; and (4) insert an accumulator in the dry air manifold to permit utilization of the automatic pressure controller.

It is believed that more simpler vapor recovery could be achieved with a pressurized desiccation system. A flow diagram for a pressurized system is presented in Fig. 21. Flow rates are based upon the results of this test. It is assumed that short-term overloads would be handled by a standby system. The flow in the figure is similar to the installed system except that the air is compressed to 100 psig. The desiccators are regenerated by expanding a small portion of the 100-psi dry air through the idle bed to atmosphere.

Pressurized desiccators would eliminate the reactivation heaters, blowers, and air coolers, and could be operated without a Freonsystem. In addition, the resultant quality of the air supply could be as low as 1 ppm.

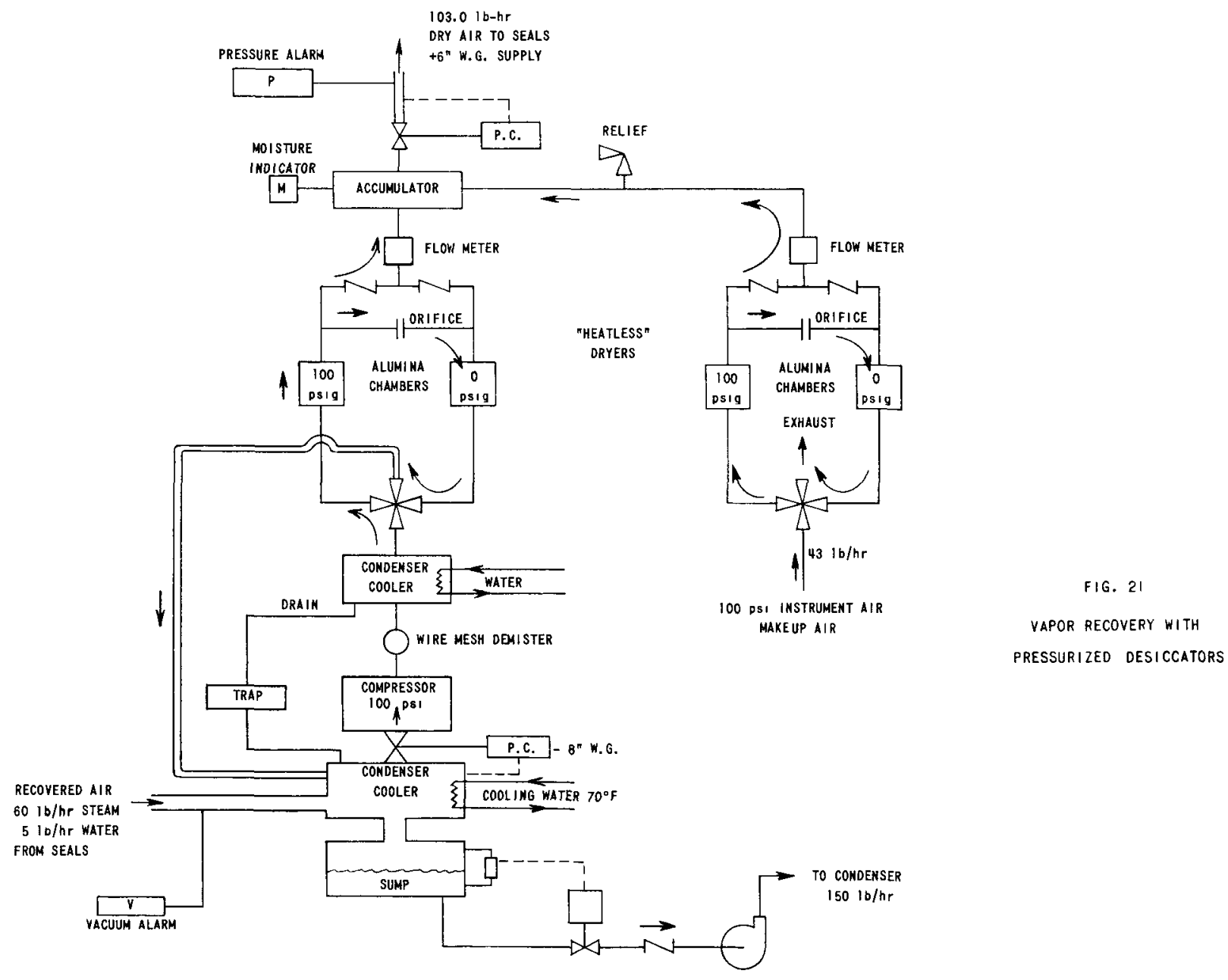




\section{ACKNOW LEDGMENT}

The authors wish to acknowledge the participation of Mr. Henry Shroka of Sargent and Lundy Engineers who worked with the authors throughout the instrument installation, testing, and data analysis.

The following people have contributed to the preparation and conduct of these tests:
R. Beyerau
Sargent and Lundy Engineers
R. Brave
Sargent and Lundy Engineers
C. Spransy
Allis-Chalmers Manufacturing Co.

\section{REFERENCES}

1. D. F. Babcock, et al., Heavy Water-moderated Power Reactors, A Status Report, DP-480 (March 1960).

2. ANL-5607, The EBWR Experimental Boiling Water Reactor (May 1957). 